\title{
78- Antik dönemde yapılan çeviri faaliyetleri: Çevirilerin niteliği ve çevirmenlerin konumu üzerine bir inceleme
}

Recep HATIPOĞLU ${ }^{1}$

APA: Hatipoğlu, R. (2021). Antik dönemde yapılan çeviri faaliyetleri: çevirilerin niteliği ve çevirmenlerin konumu üzerine bir inceleme. RumeliDE Dil ve Edebiyat Araştırmaları Dergisi, (25), 1258-1280. DOI: 10.29000/rumelide.1032587.

$\ddot{\mathbf{O z}}$

Geçmişten günümüze medeniyetler arasında kurulan ilişkilerde, doğal olarak taraflar önce birbirlerine karşı ihtiyatlı davranmış, daha sonra bu tanışmayla birlikte tartışmalar başlamış ve muhatabını daha iyi tanımak için de tercüme hareketleri ortaya çıkmıştır. Hemen her medeniyet başka medeniyetler ile etkileşime girmiş ve tercümeler vasıtasıyla bilgi, teknoloji, dil, kültür bağlamında kendini daha da geliştirmiş, sonrasında da başka medeniyetlere etki etmiştir. Tercüme vasıtasıyla eski Sümer ve Mısır Yunan’a ulaşmış, Yunan kültürü Latin ve İslam ülkelerine, İslam ve Latin kültürleri de yine tercümelerin zeminini hazırladığı Rönesans yoluyla Avrupa'ya ulaşmıştır. Tarih boyunca gerçekleştirilen bu faaliyetler, önceleri başta tarih disiplini olmak üzere çeşitli bilim dalları tarafından incelenmiş, daha sonra 20. yüzylın ikinci yarısından itibaren kuramsal altyapısını oluşturan çeviribilim disiplini çerçevesinde ele alınmaya başlanmıştır. Ürün, süreç ve kavram olarak çeviri son zamanlarda önemli bir ilgi odağı olmuş ve bunun sonucu olarak da çeviri tarihine ilgi artmıştır. Çeviri tarihi çalışmaları, Woodsworth tarafından, zaman ve yerle sınırlı tarihler, çeviri türlerine odaklanan tarihler, çeviri tarihinde önemli dönüm noktalarını ele alan tarihler ve çevirmenleri konu alan tarihler olarak sınıflandırılmaktadır. Bu çalışmada, insanlık tarihinin başlangıcından, erken dönem Ortaçağ’a kadar devam eden ve Antik Çă̆ veya İlk Çă̆ olarak adlandırılan dönemde gerçekleştirilen çeviri faaliyetleri ve yapılan çevirilerin niteliği ile çevirmenlerin konumu üzerinde durulacaktır.

Anahtar kelimeler: Antik dönem, ilk çă̆, çeviri tarihi, çeviri, çevirmen

\section{Translation actvities in the Antique Age: A study on the characteristics of the translations and the situation of the translators}

\begin{abstract}
From past to present, the communities not knowing each other naturally exercised caution between them first in terms of international relations, and they have began to discuss after having met each other; as a result, translation activities arose so that they could know the other party. Almost every civilization interacted with other civilizations and they improved themselves through translations in terms of knowledge, technology, language and culture, and the affected the other civilizations. Ancient Sumerian and Egyptian cultures were transferred to Hellenic people, the hellene culture was transferred to Latin and Islamic countries through translations and, Islamic and Latin culture were transmitted to Europe by means of Renaissance based on translations. Translation activities carried out throughout history were examined under different disciplines such as history at first and now, they have been investigated under the discipline of Translation Studies in addition to ther disciplines.
\end{abstract}

Doktora, Sakarya Üniversitesi, Çeviribilim (Sakarya, Türkiye), rhatipoglu@uludag.edu.tr, ORCID ID: 00oo-0002-7229180X [Araştırma makalesi, Makale kayıt tarihi: 01.10.2021-kabul tarihi: 20.12.2021; DOI: 10.29000/rumelide.1032587] 
Translation, as a product, a process and a concept, has attracted attention in recent years and translation history has begun to draw attention. Woodswarth divides the studies in Translation History into four groups: Historical studies based on time and location; types of translation; important milestones in Translation History and translators. In this study, the translation activities will be examined, from the Antique age to the early Medieval age, and the information of the quality of the translations and the situation of the translators. In this study, the translation activities in the Antique age, the characteristics of the translations and the situation of the translators wll be examined.

Keywords: Antique age, translation history, translation, translator

\section{Giriş}

Çok eski çağlardan günümüze çevirmenler ve çeviri, farklı milletler, ırklar, kültürler ve kıtalar arasında çok önemli bir köprü olmuş, çevirmenler sayesinde dil bariyerleri aşılmış ve böylece bilgi, yazının bulunmasıyla birlikte çeviriler sayesinde toplumlar arasında dolaşarak kültürlerin gelişimine katkıda bulunmuştur. Çevirinin, olağanüstü bilgi sahasında bir keşif yolculuğu olduğu ve çevirmenlerin yüzyıllardır yapmış oldukları çalışmalar değerlendirildiğinde, alıcı konumdaki kültürlerin bu çalışmalarla kendilerini zenginleştirdiklerini vurgulayan Delisle ve Woodsworth (2012: önsöz), İ.Ö. 3 . yüzyılda Yunanlı bir köle olan Livius Andronicus'un, amansız Romalıları Yunan edebiyat hazineleri ile tanıştırdığını, 8. yüzyılda yaşamış İranlı tercüman Ibn al-Muqaffa'nın Hint Bidpai Fablları (Fables of Bidpai) ile Arap kültürünü zenginleştirdiğini ve bunların daha sonra Jean de La Fontain'in fablları için ilham kaynağı olduğunu belirtir. Bu konuda binlerce örnek olduğunu dile getiren Delisle ve Woodsworth (2012: önsöz), yazar olmadan önce bir çevirmen olan Geoffry Chaucer'ın, balad, masal ve fablları ülkesinin kültürüne kazandırdığını, 18. yüzyıl Hintli astronom Jagannatha'nın Batlamyus (Ptolemy)'un Almagest ve Euclid’in Elements eserlerini Arapçadan Sanskritçeye çevirdiğini ifade eder. Bütün kültürlerde olduğu gibi, Türk kültürü ve edebiyatı da farklı kültürlerden etkilenmiş, çeviri yoluyla Türk edebiyatına yeni türler dahil olmuştur. Paker (1987: 31), Yeni Türk edebiyatı'nın 19. yüzyılın ikinci yarısında, Tanzimat döneminde, Avrupa ve özellikle Fransız etkisiyle doğduğunu ve bu dönemde atılan ilk adımın Fransız edebiyatından Türkçeye yapılan çeviriler olup, her biri bir yazın türünü (Batı şiirini, felsefî diyaloğu ve romanı) temsil eden ilk üç çevirinin 1859'da yayınlandığını belirtir.

Geçmişten günümüze hiçbir kültür tek başına var olmamış, her kültür başka bir kültürden etkilenmiş ve böylece zenginleşmiştir. Kültürlerarası etkileşimde çevirinin rolü yadsınamaz bir gerçek olup, sosyal hayatın birçok alanında, gerek ulusal gerekse uluslararası çapta dilbilimsel ve kültürel açıdan çok önemli bir role sahiptir. 1978 yllında Nobel Edebiyat Ödülü sahibi olan Isaac Bashevis Singer çevirinin, "uygarlığın özü” olarak kalacağını ifade eder (Guidère, 2008: 7). İnsanoğlunun yaklaşık dört milyon yıldır yeryüzünde bulunduğunu ancak altı bin yıldan daha az bir süredir yazdığını belirten Delisle ve Woodsworth (2012: 3), ilk yazı biçiminin Sümer çivi yazısı olup tarımsal ve ticari kayıtların tutulmasını kolaylaştırmak için Mezopotamya'da ortaya çıtığına, daha sonra yazının Mısır ve Çin'de görüldüğüne ve yazının bulunmasıyla birlikte tarih ve çevirinin de ortaya çıttı̆̆ına dikkat çeker. Bilgi ve kültürün çeviri kanalıyla bir toplumdan diğerine aktarıldığı bilinen bir gerçektir. Nitekim Ülken (2011: 5) medeniyetlerin uyanışının çeviri devri ile başladığını vurgulayarak Eski Yunan uyanışının Anadolu, Fenike, Mısır çevirileriyle; Türk Uygur uyanışının Hint, İran, Nasturi çevirileriyle; İslam uyanışının Yunan, Hint çevirileriyle ve yeni Garp uyanışının da, içinde Türk, Arap ve Acemin yer aldığı İslam, Yahudi ve Yunan çevirileriyle mümkün olduğunu belirtir. Yazının bulunması ile çeviri başlamış ve böylece her devirde olduğu gibi İlkçă̆'da da medeniyetler arasında bilgi ve kültür aktarımı başlamıştır. 
İlkçağ veya Antik Çağ olarak adlandırılan dönem, çeşitli kaynaklarda insanlık tarihinin başlangıcından erken dönem Ortaçağ’a kadar geçen dönem olarak adlandırılmaktadır. Ballard (2013: 9), İlkçă veya Antik Çağ olarak ifade edilen dönemin sınırları ile ilgili olarak farklı fikirler olsa da, yazının ortaya çıkışı olan İ.Ö. 4000-300o ve son Batı imparatorunun tahttan inişi olan 476 yılları arasını kapsadığını ifade eder. Bu çalışmada, İlkçă̆ olarak adlandırılan dönemde tarih sahnesinde yer alan Eski Mısır, Mezopotamya ve Roma dönemlerinde yapılan çeviriler ele alınacak ve çevirilerin yanı sıra çevirmenler hakkında da bilgi verilecektir.

\title{
2.Eski Mısır'da çeviri faaliyetleri
}

Kuiper (2011: 15) eski Mısır uygarlığının kuzeydoğu Afrika'da İ.Ö. üçüncü binyılda geliştiğini ve eski Misır kavramının, geleneksel olarak tarih öncesi dönemden İ.S. 7. yüzyllda gerçekleşen İslam fethine kadar kuzeydoğu Afrika'ya işaret ettiğini belirtir. Ballard (2013: 9) Firavunların hüküm sürdüğü Mısır’ın İ.Ö. yaklaşık 3000 yılından (ilk sülale tarafından Mısır devletinin kuruluşu) İ.Ö. 332 yılına dek (İskender’in gelişi) sürdüğünü ifade eder. Eski Mısır’n coğrafî ve kültürel açıdan Yukarı Mısır ve Aşağı Mısır olarak ayrıldığını belirten Kuiper (2011: 9), Yukarı Mısır’n, Nil deltasının güney bölgesinde, Aşağ Mısır'ın ise Nil Nehrinin yelpaze şeklini alarak Akdeniz’e döküldüğü kuzey ovalarında yer aldığını dile getirir ve Nil kıyıları boyunca papirus olarak bilinen çimen gibi bitkilerin yetiştiğini ve çok amaçlı bitki sapının liflerinin yelken kumaşı ve kıyafet yapımında kullanıldığını, ancak tarihî açıdan en önemli kullanım amacının yazı yazmak için kullanılması olduğuna dikkat çeker. Hiyeroglif yazısının kullanımıyla birlikte Eski Mısır'da gerçekleştirilen yazınsal çalışmalar, matematik, astronomi, tıp ve sihir ile çeşitli dini metinleri kapsıyordu (Kuiper, 2011: 23).

Herodot'un naklettiğine göre İ.Ö. 5. yüzyl ortalarında Mısır'da sosyal sınıflar yedi gruba ayrılıyordu ve bunlardan biri de tercümanlar sınıfı idi; soylu sınıftan kabul edilen tercümanların varlığı, Eski İmparatorluk'tan itibaren, Asvan şehri seviyesinde bulunan Eléphantine adası karşısında yer alan bir şehir mezarlığında bulunan yazıtlarda kanıtlanmıştır (Ballard, 2013: 9).

\begin{abstract}
Mısırlılar, daha sonra Yunanlılarda olduğu gibi, diğer milletleri ve dilleri 'barbar' olarak kabul etmelerine rağmen, dış dünya ile siyasî ve ticarî ilişkileri sürdürmek zorundaydılar. Eléphantine prensleri, altıncı hanedan (İ.Ö. 2423-2263) firavunları için Nubie ve Sudan'da görev yapmışlardır. O dönemde ilk büyük çağlayan, Nubie ile bir tür doğal bir sınır oluşturuyordu ancak etnik sınır Silsilèh denilen yerin kuzeyinde doksan kilometre mesafede bulunuyordu ve böylece Assan bölgesi nüfusu iki dilli, Eléphantine prensleri de melez idi. Yazıtlarda bunların isimleri mevcut olup (Harkhuf, Sabni, Mechu) 'baş tercüman' ünvanına sahip oldukları belirtilmektedir. Tercüman olarak bu kişiler, aynı zamanda diplomat, özel görevliydiler ve yazıtların temelini oluşturan da bu kişilerin anlattıklarıydı. Bunların en önemlilerinden biri, Prens Harkhuf'un Kral Merenré ve kendisinden sonra gelen II. Piopi adına Nubie ve Sudan'da gerçekleștirdikleri dört yolculuğu anlatır. Bu prenslerin görevleri güney ülkeleri ile sınırlı değildi ve bazıları Byblos'a gönderilmişlerdi. Diplomatik tercümanlar Nubie dışındaki diğer bölgelerle olan ilişkileri sağlıyor ve tercümanlar da firavunların askerî seferlerine eşlik ediyorlardı (Ballard, 2013: 10).
\end{abstract}

Mısır hiyerogliflerinin, 'gökyüzü’ veya 'insan' gibi olguların doğrudan temsil edilmesi için kullanılan işaretler olan ideogramlardan ve konuşulan sözcüğün tamamının veya bir kısmının sesini temsil eden fonetik işaretlerden meydana geldiğini dile getiren Shaw (2004: 72), bu nedenle yazı ve sanat arasındaki ilişkilerin, diğer birçok kültüre kıyasla Firavun Mısır’nnda çok daha güçlü olduğunu, bina ve heykelleri süsleyen hiyeroglif yazılarında, 'kaz’ veya ‘baş' gibi basit kelimelerin yazılışının, bir ölçüde

sanatsal bir alıştırma ve sözlü iletişim eylemi olduğunu belirtir. Üçüncü bir tür hiyeroglif 'belirleyici' olup bütün kelimenin anlamını belirtiyordu ve böylece yiyecek, içecek anlamına gelen çok çeşitli 
kelimeleri veya 'bilmek', 'işitmek' gibi düşünce ve akıl ile ilgili soyut kelimeleri ifade ediyordu (Shaw, 2004: 72).

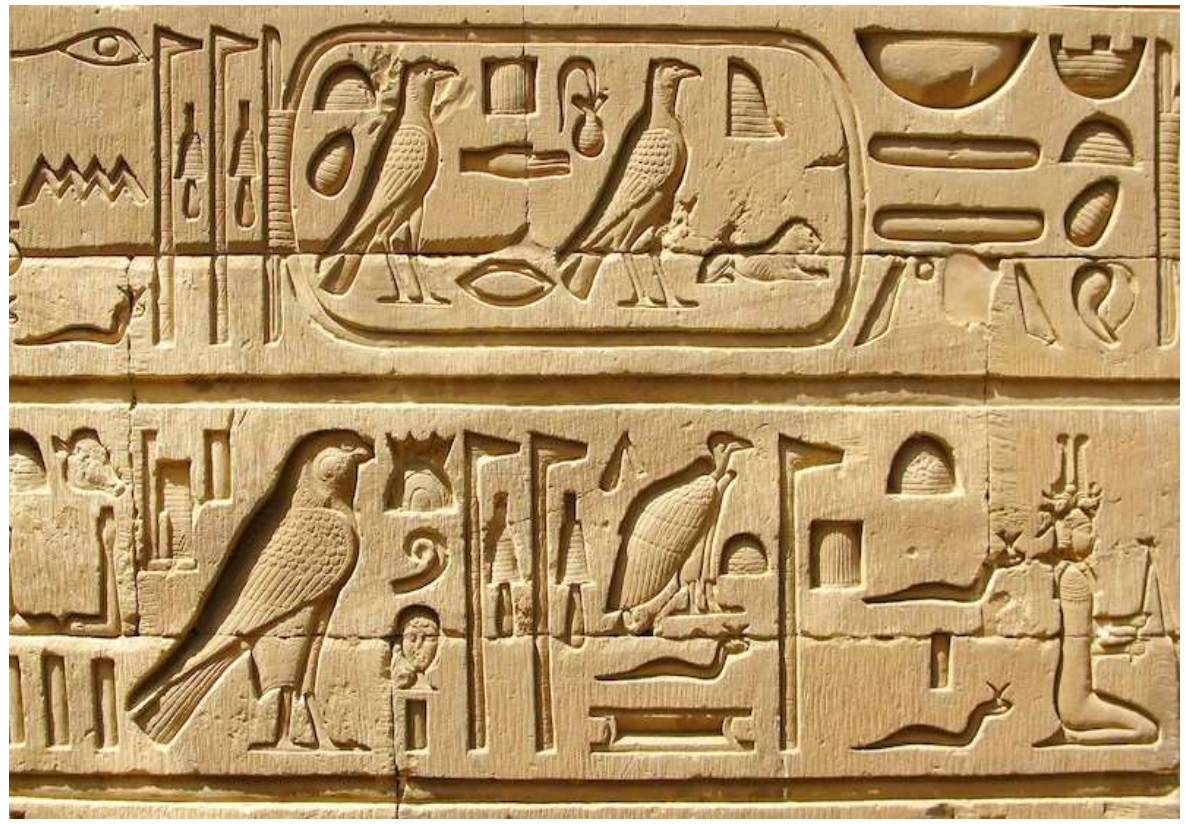

Hiyeroglif yazısı

Kaynak: https://arkeofili.com/google-yapay-zeka-destekli-hiyeroglif-cevirmeni-duyurdu/

Eski Mısır'dan kalan metinlerin birçoğu, tapınak ve mezarların duvar ve tavanlarını süsleyen resim ve rölyefleri tamamlamak ve şerh etmek için oluşturulduğunu belirten Shaw (2004: 73), Mısır yazı ve sanatının görünüş ve fonksiyonunun dinî inanış ve cenaze töreni uygulamalarıyla yakından ilişkili olduğuna vurgu yapar. Yazınsal metinlerin matematik, astronomi, tıp ve büyünün yanı sıra çeşitli dinî metinleri içerdiğine dikkat çeken Kuiper (2011: 23), bu metinlerin Mısır dilinin geç safhalarında yazıldığını belirtir. Ballard (2013: 10), yazının, Mısır geleneğine göre ilahî kaynaklı olduğunu ve bilginin, bilgeliğin ve büyünün tanrısı olan Thot'a atfedildiğini belirtir ve dillerin farklılaşmasının da kendisine atfedildiğini vurgulayarak tanrıların habercisi ve yazıcısı olarak kabul edildiğini, bundan dolayı yazıcıların ilki ve koruyucusu olarak görüldüğünü ifade eder. Yazının Mısır'da çok geç ortaya çıktığını belirten Ballard (2013: 10), bilinen en eski hiyerogliflerin İ.Ö. 3. binylla uzandığını ve önceki biçimlerinin var olduğunun düşünüldüğünü belirtir ancak erken ortaya çıkmasına rağmen çeviri konusunda çok az kanıt bulunduğunu dile getirir. Eski Mısır'da bu faaliyet ile ilgili olarak bize ulaşan görüntü, o dönemde ülkenin kültürel durumunu ortaya koymaktadır ve yazı, her şeyden önce tarihi, savaş hikâyelerini ve bu medeniyetin dinî efsanelerini kopya etmeye yaramaktadır (Ballard, 2013: 10). O dönemin yazılı kaynakları sadece tarih, savaş hikâyeleri ve dinî efsanelerle sınırlı olmayıp başka alanlarda da çalışmalar bulunmaktadır. Ballard (2013: 10), kültürel açıdan ileri konumdaki bu durumun, resmî veya kullanım belgelerinin çevirisini hariç tutmadığını ancak bu konuda çok az kanıt bulunduğunu belirtir ve en bilinenlerinden birinin, Mezopotamya medeniyetleri ile yapılan alış verişlerle ilgili olduğunu ifade eder.

Eski Mısır'da çeviri faaliyetleri ile ilgili çok fazla kanıt bulunmamaktadır. Ancak yapılan kazılarda ortaya çıan bazı tabletler o dönemin çeviri faaliyetleri hakkında kısmen de olsa bilgi vermektedir. İ.Ö. 1370 ylına doğru Akhénaton tarafından başkent ilân edilen Tell El-Amarna yerleşim bölgesinde, üzerinde 
çivi yazısı şekilleri olan ve otuz yıllık bir dönemde çeşitli kuzey-doğu ülkeleri ile yazışmaları temsil eden 382 adet tablet bulunmuş (Ballard, 2013: 10) ve bunlar Amarna Mektupları olarak adlandırılmıştır (Shaw, 2004: 36). Arşivde yer alan belgelerin çoğunluğunun, ya Babil ve Asur gibi Batı Asya'da yer alan büyük güçler veya Suriye ve Filistin gibi tâbi devletlerle Mısır arasındaki yazışmaları içerdiğini belirten Shaw (2004: 36), bu tabletlerin muhtemelen el yazması eğitimi ve çeviri sürecini içerdiğini, ayrıca içinde Akad ve Mısır dilinde sözlük benzeri bir liste, hece tablosu bölümü, birkaç el yazma alıştırması ve edebî metinleri kapsadığını dile getirir. $\mathrm{Bu}$ arşivlerin çoğunluğunun gelen mektuplardan oluştuğunu ve içeriklerinin, yönetim işlerini, devlet adamları arasındaki ilişkileri, evlilik hazırlıklarını, hediye gönderimi, vb. konuları ele aldığını belirten Ballard (2013: 10-11), Moran (1987)'dan aktararak, büyük güçlerle yapılan yazışmalarda, metnin önce Mısır dilinde kaleme alınıp daha sonra haberci tarafından götürülecek olan çevirisinin yapıldığını ve bazen orijinal metnin de gönderildiğini vurgulayarak, gelen mektupların El-Amarna mektuplarının çoğunluğunu oluşturduğunu ve firavuna, yapılan çeviri şekli belirtilmediği için, bazı memurların, doğrudan mesajın anlamına girip sözlü çeviri yapmış olabileceklerini ifade eder.

\section{Mezopotamya'da çeviri faaliyetleri}

Köroğlu (2006: 11), Mezopotamya adının, Antik yazarlar tarafından Firat ve Dicle nehirleri arasında kalan, günümüzdeki Irak topraklarının bir bölümünü tanımlamak için, mesos (orta) ve potamos (ırmak) sözcüklerini birleştirerek türettikleri bir kavram olduğunu, başlangıçta bölgenin tek bir adı olmayıp, güney bölümünün Sümer ve sonrasında ünlü Babil kentinden dolayı Babilonya, kuzeyinin ise Asur ülkesi olarak anıldığını belirtir. Ballard (2013: 11) da benzer bir ifadeyle, Mezopotamya'nın, kuzeyde Asur, güneyde Babilonya olmak üzere iki büyük bloktan meydana geldiğini ve bu iki bölgenin, bazen birlikte yaşadıklarını, hakimiyet ve yayılma aşamasına geçmeden önce aralarında mücadele ettiklerini belirtir. Klasik ifadeyle Dicle ve Firat nehirleri arasında yer alan Mezopotamya topraklarının çoğunluğu günümüz Irak sınırları içinde, bir kısmı Suriye'nin doğusunda, çok küçük bir bölümü de Türkiye ve İran sınırları içinde yer almaktaydı ve güney Mezopotamya - eski Babilonya - daha özel bir ifadeyle Sümer, dünyayı günümüz şehir toplumuna dönüştüren birçok gelişmeye şahitlik etmiştir (Mcintosh, 2005: 3).

Ballard (2013: 11), kuzey komşuları Akadların aksine Sümerlerin Sami olmadıklarını ve Sümer dilinin de Sami dili olmayıp Asya dili olduğunu, 4. binyılda Mezopotamya'nın güneyinde konuşulan bu dille ilgili olarak yaklaşı İ.Ö. 3200 tarihinden itibaren yazılı eserler bulunduğunu belirtir. Mcinthosh (2005: 43), İ.Ö. 3. binyılda güney Babilonya halkı Sümerce konuşurken kuzeyde Akad dilinin ana dil olduğunu ve Babilonya'da her iki dili konuşanların da bulunduğunu belirterek, İ.Ö. 1800 civarında konuşma dili olarak Sümer dilinin ortadan kaybolduğunu ancak birçok yazıt ve edebî metinlerde hâlâ kullanıldığını ve bu dilin başka hiçbir dille akrabalığı olmadığını ifade eder. Buna karşılık Akad dili yaygın Sâmi dilleri grubundan biriydi ve Eski Akad dili İ.Ö. yaklaşık 2000 yılına kadar güney Mezopotamya'da konuşulmuş, bu tarihten sonra kuzeyde Asur dili, güneyde Babilonya dili olmak üzere iki lehçe gelişmiştir (Mcinthosh, 2005: 43). İ.Ö. 3. binyılın sonundan itibaren, Akadların Sümerlerden yazı sistemini ödünç aldıklarını ve kendi dillerini zorla kabul ettirdiklerini ancak Latincenin Ortaçağ'dan itibaren yazı dili olarak kullanılması gibi Sümercenin de yazı dili olarak kullanılmaya devam ettiğini belirten Ballard (2013: 12), Sümerlerin en büyük değerlerinden birinin, sadece yazıyı icat etmeleri değil, aynı zamanda bir sözlükbilimi formu oluşturmaları olduğunu vurgular. Akadlarla birlikte bu bilim (sözlükbilim) yeni bir şekil almış, Sümer kültürünün korunması, edebiyatının incelenmesi ve taklit edilmesi, Sümerce-Akadca 
iki dilli sözlüklerin hazırlanması yolunu açmış ve daha sonraki bir dönemde, yani Ahameniş İmparatorluğ $\mathrm{u}^{2}$ döneminde, Assuerus

saltanatı sırasında Yahudilerin esaretini canlandıran Esther kitabında çevirmenlerin varlığı (veya yazıcılar tarafından gerçekleştirilen bir çeviri faaliyeti) hakkında kanıt bulunmaktadır (Ballard, 2013: 12).

Chrobak (2013: 88), Babil kulesinin yıkılışından itibaren veya daha öncesinden, farklı dilleri konuşan insanların resmî veya resmî olmayan ortamlarda siyasî, ekonomik, askerî, dinî ve özel konularda hem bağımsız olarak hem de az ya da çok nitelikli tercümanlar vasıtasıyla iletişim kurmaya çalıştıklarını belirterek, Yakındoğu'da tercümanlık mesleğinden ilk defa Antik Sümer'de bahsedildiğini ve bu dönemde tapınak ve saray ekonomisinde ticarî ve siyasî görüşmelerde tercümanın rolünün çok önemli olduğunun elde edilen tabletlerden anlaşıldığına dikkat çeker. Mezopotamya'da ilk zamanlar tercümanlığın daha çok kâtiplik (yazmanlık) olduğunu ancak daha sonra bu kişilerin tercümanlık alanında uzmanlaştıklarını vurgulayan Chrobak (2013: 90), diplomatik görüşmelerde tercümanlardan bahsedilmemesinin, bu mesleğin olmadı̆̆ anlamına gelmediğini, İ.Ö. ikinci binylın ortalarından itibaren Akad dilinin Yakındoğu'da resmî diplomasi ve ticaret dili olduğunu ancak devlet başkanlarının yine de yabancı dilleri az çok akıcı konuşan tercümanlardan yararlandığını belirtir ve Gelb (1968: 92103)'den aktararak, bu dönemde, tabletlerden öğrenildiğine göre tercüman anlamına gelen eme-bal sözcüğünün inim-ball, daha sonra kaynağı tam olarak bilinmeyen ve 'bildirmek, tercüme etmek' anlamına gelen muhtemelen Hititçe Tarkummai sözcüğünden türediği düşünülen ve Eski Asurcada yer alan targumannu sözcüğüne dönüşerek İbranicede meturgeman, Arapçada tarjuman; Roman dillerinde trujaman, truchement, turcimanno; Yunancada dragoumanos ve diğer birçok Avrupa dilinde dragoman şeklinde kullanıldığını ifade eder.

Yazman ve bilginlerin elit sınıfa ait olduklarının altını çizen Pearce (1995: 2265), Mezopotamya krallarının siyasî hırslarını imparatorluğa yönelttikleri için tercüman gereksinimi ortaya çıtığını, daha önce iki dilde yazılı ve sözlü olarak eğitim görmüş olan yazmanların doğal olarak bu görevi yerine getirmek üzere görevlendirildiklerini vurgulayarak nasıl çalıştıkları konusunda kaynaklarda çok az bilgi bulunduğunu belirtir.

Bertman (2003: 148), Mezopotamya'nın epik şiir, tarihî kronikler, adlî belgeler, kehanet metinleri, ilahiler, dualar ve ağıtlar, mektup ve atasözleri, toplumsal hiciv ve erotik şiirler gibi çok zengin bir hazineye sahip olduğunu belirterek eski Mezopotamya'nın en önemli şiirlerinden birinin Gılgamış Destamı olduğunu ifade eder. Çiviyazısı formunda yazılmış olan Gılgamış Destanı'nın, İncil'de yer alan Yaratılış (Genesis) kitabının 6-9 bölümlerinde bulunan tufan ile ilgili anlatımlar ile Gılgamış Destanı'nın XI. Tabletinde anlatılan Babil gelenekleri arasında şaşırtıcı benzerlikler olduğunu vurgulayan Njozi (1990: 303), bu iki metnin tarihî açıdan birbiriyle ilişkili olduğuna vurgu yapıldığını ancak bu ilişkinin niteliğinin doğruluğunun kanıtlanması gerektiğini vurgular. Ballard (2013: 13), Gılgamış’ın çeviri yoluyla yayılmasının çok büyük olduğunu çünkü Kramer (1994: 264)'in ifadesiyle, Küçük Asya'da, şiirin birçok bölümünün Hurri3 ve hatta Hint-Avrupa dili olan Hitit dilinde çevirileri olan birçok tablet bulunduğunu, destanın Babil dilindeki metninin, çok eski dönemlerde Ortadoğu'nun hemen her yerinde çevrildiğini ve benzerlerinin yapıldığını (öykünüldüğünü) belirtir.

İ.Ö. 6. Yüzyllda Büyük Kiros tarafindan kurulan Pers devleti.

Hurrice veya Mitannice, İ.Ö. 3. ve 2. Binyllar arasında Anadolu ve Kuzey Mezopotamya'da hüküm süren Hurriler (veya Mitanniler) tarafından konuşulmuş bir dil. 


\title{
4.Eski Yunan'da çeviri faaliyetleri ve İbranîce metinler
}

\subsection{Eski Yunan'da çeviri faaliyetleri}

Kendileri kaynak olmaları nedeniyle Yunanlılar pek çeviri yapmamış ve Yunanistan’ın uygarlığın beşiği olması ve çeşitli edebiyat formlarının burada ortaya çıkmış olması nedeniyle Batı, uygarlık tarihi boyunca kendileri için konu, biçim çıarabilmek, bir tarz oluşturabilmek, taklit etmek veya daha iyi fikir ve biçime ulaşabilmek için yeni bir çeviri ile saygı göstermek amacıyla yönlerini buraya çevirmişlerdir (Ballard, 2013: 13). Yahudilerin, tarihin bazı noktalarında başka uygarlıklardan ödünç alabildiklerini (örneğin Akadlar), ancak kültürel ve özellikle dinî nedenlerle çevirisi yapılan kurucu metinlerin üreticisi veya temsilcisi olduklarını dile getiren Ballard (2013: 13), Batı uygarlığındaki yaklaşımlarını belirleyen ve etkileri günümüze kadar hissedilen, dil ve çeviri ile ilgili düşünceler içerdiklerini ifade eder.

Medeniyet uyanışları bağlamında ilk uyanış hareketinin Eski Yunan uyanışı olduğunu dile getiren Ülken (2009: 9), Batıda özellikle bu devrin hayranları arasında, bu uyanışın kendiliğinden doğmuş gibi görüldüğüne ve bu nedenle 'Yunan mucizesi' denmesinin bir âdet haline geldiğine vurgu yapar, ancak yapılan araştırmalarda Yunan ilminin üç kaynaktan geldiğini belirterek bu kaynakların da Sümerler, Fenikeliler ve Misırlılar olduğuna işaret eder. Antik Yunanda çevirmenin konumuyla ilgili olarak Yücel (2007: 19), çevirmenin tanrının habercisi, tüccarların, gezginlerin, hırsızların ve bereketin de tanrısı olan Hermes'le özdeşleştirildiğini belirtirken, Ballard (2013: 14) bunun, çeviri üzerine yazılan yazılarda çokça kullanılan sembolik bir şey olduğunu ifade eder ve hem tuhaf hem de Yunan uygarlı̆̆ının bir özelliği olarak, çevirinin araştırma nesnesi olarak çevirinin kendisinin göz ardı edildiğini belirtir.

Herodot (1992: 186-187)'un kültürel ödünçlemelerle ilgili olarak, Yunanistan'ın hemen hemen tüm tanrılarının isimlerini Mısır'dan aldığını ve Yunan kehanetlerinin kaynağının Mısır’a bağlandığını dile getirdiğini belirten Ballard (2013: 15), çeviri konusunda resmî olarak pek çeviri yapmadıkları gerçek olsa da, Herodot'un yazılarının bir çeviri biçimini ortaya koyduğunu, Senustres'in halefi olan bir firavunun adının Yunan dilinde ifadesinin daha önce Platon'da da görüldüğü gibi, Greklerin özel isimleri Yunancalaş̧ırdıklarının göstergesi olduğunu ve bunun da bir çeviri biçimi olduğunu dile getirir.

\begin{abstract}
Yunan uygarlığında çeviri ilebağlantılı iki faaliyet bulunmaktadır: kehanet uygulaması ve dil üzerine düşüncede ilk adım. Yunanlıların Delfi'de, Olimpos'ta Dodona'da kâhinleri vardı ve geleceği danışmak için oraya gidilirdi. Tanrılar çeşitli işaret biçiminde cevaplarını verirlerdi: rüyalar, rivayetler, sözler, vb. ve tercüman ('Ermeneus') da danışanlar için yorum yapardı. (...) Eshilos, Sofokles, Pindare vb. ile şiir ve tiyatronun yayıldığına şahitlik eden İ.Ö. 5 . ve 4 . yüzyıllar hiçbir çeviri ile kendini göstermez. Diğer dillerin vebaşka uygarlıkların çoğunun küçümsenmesi, Yunanistan'da resmî bir çeviri uygulamasının olmadı̆̆ını göstermiştir (Ballard, 2013: 15).
\end{abstract}

Yunan medeniyetinin Mısır kaynaklarından geldiğini belirten Ülken (2009: 12), matematiği kuranlardan Pythagore’un yllarca Mısır'da eğitim gördüğünü ve orada Harpédonaptes denilen rahiplerden bir tür mistik matematik öğrendikten sonra bunu büyük Yunanistan denilen güney İtalya'da bir ilim ve tarikat halinde bir araya getirdiğinin eskiden beri bilindiğine işaret eder.

\section{2. İbranîce metinler}

İbranîce metinlerin başlangıçta İbranî toplumunun sözlü geleneğine bağlı olduğu ve İ.Ö. 13oo'den itibaren rulolar üzerine kopya edilmeye başlandığının tahmin edildiği belirtilir (Jacob, 1977: 22-23; akt. 
Ballard, 2013: 16). İ.Ö. 721 yllına doğru Asurlular İsrail'in başkenti Samariya’yı4 (kuzeyde) ele geçirip halkı sürgün etmiş, İ.Ö. 587 yılında da Babilonya kralı Nebukadnezar Kudüs’ü yıkmış ve nüfusun büyük bir bölümünü sürgüne göndermiştir ve bu da Yahudiye krallığının (güneyde) sonu olmuş, böylece kutsal metinlerin de ortadan kalkması sonucunu doğurmuştur (Ballard, 2013: 16). Metinlerin birçok gruba ayrıldığını belirten Jacob (1977; akt.Ballard,2013: 16), bunların beş kitaptan oluşan ve Katoliklerin İ.S. II. Yüzyıldan itibaren Yunancadan gelen ve 'beş rulo' anlamına gelen Pentateuk adını verdikleri Torah (veya Tevrat), 12 tarih kitabı, 5 şiir kitabı ve Yahudi geleneğinde Nebiim (veya Nevi’im)5 olarak geçen 17 kehanet/önceden bildirme kitabı olduklarını ifade eder ve çeviri açısından cezbedici olan kutsal kitap Torah'ın, çeviri uygulaması ve araştırması açısından önemsiz sayılamayacak önemli dilbilimsel varsayımlar içerdiğini dile getirir. Torah'ın Tanrı sözü olması nedeniyle, çeviri kavramı üzerinde yadsınamaz bir etkisi olacağını ifade eden Ballard (2013: 16), buradan üç sonuç ortaya çıktığını ve bunların, yoruma dayalı bir çeviri gelişimi, sözcüğü sözcüğüne çeviri tercihi ve dillerin belirli bir hiyerarşisi olduğunu belirtir.

\begin{abstract}
Metnin ilâhî kaynaklı olması, anlama doğrudan girmeye izin vermez ve sonucun her zaman kesin olmaması, tamamen bir yorum çalışması gerektirir ve bu da, yapılan girişimin riskli niteliğinin tamamen farkında olarak anlamı bulabilmek için metnin iyice incelenmesi arzusu doğurur zira büyük edebiyat metinleri gibi, kutsal, ilham edilmiş olan bu metin, ilk bakışta göründüğünden daha fazla anlamı içinde barındırır. Kutsal kitap etrafında gelişen ve Midrash ve Talmud'u meydana getiren birçok yorum da bu yorumsal gelenekten doğmuştur. Bazı Yunanca metinlerde daha önce görülen çeviri hakkındaki kuşku, bu durumda daha da şiddetli bir hâl alır zira Tanrının sözlerini bozma korkusu sözcüğü sözcüğüne bir çeviri türü ortaya çıkarır ki bu da İbranîce bilmeyen biri için okunamayan bir metnin ortaya çıkmasına neden olmaktadır. (...) İlahiyat açısından çeviride ihlâl edici bir nitelik vardır çünkü iletişim yasağının aksi yönde yol alır ve bazı alanlarda sebep olabileceği, şüphe ve memnuniyetsizlik duygularının birbiriyle bağlantılı bir şekilde ortaya çıtığı görülür. Dinî olana gelince, kaygı en üst düzeydedir zira genellikle anlaşlamaz veya çok karmaşı ve anlama ihanet etmemek için biçime çok fazla bağlı olan anlamı aktarma iddiası söz konusudur. Bu durumda çeviri, dine küfür olmaktadır. (Ballard, 2013: 17).
\end{abstract}

\title{
5. Ptolemaios Mısır'ında çeviri faaliyetleri
}

Hölbl (2001: 1), eski Mısır tarihi ile ilgili olarak yapılan çalışmalarda dönemin dinî koşullarının ve gelişmelerinin dikkate alınması gerektiğini zira siyasî ve dinî-kültürel olayların karşılıklı olarak birbirine bağlı olduğunu ve birbirlerini etkilediğini dile getirir. Bu durum çeviri faaliyetleri açısından da geçerli olup çevirisi yapılan eserlerin yazıldıkları dönemin siyasî, kültürel ve eski Mısır gibi toplumların dinî yapılarının da göz önünde tutulması gerekir.

Büyük İskender İ.Ö. 323 tarihinde öldükten sonra generalleri imparatorluğu paylaşmış ve satraplıkların6 bölüşümünde en iyi olanı yani Mısır, İ.Ö. 360 tarihinde Makedonya'da doğmuş olan Lagos'un oğlu Ptolemaios'a (Ptolemy) tahsis edilmişti ve burası, konumu itibariyle zengindi ve gerçekte bağımsızdı (Hölbl, 2001: 13). Mısır o dönemlerde iki dillidir; Yunanca resmî dil olup hakim sınıfın dilidir ve eski Mısır dili, yerli nüfusun büyük bir bölümünün dili olarak kullanılır. Bu dönemle ilgili olarak çeviri faaliyetleri açısından Ballard (2013: 18), klasik dönem Yunanlılarının ve genel olarak Peleponnes Yunanlılarının pek çeviri yapmadıklarını ancak Ptolemaios'un, özellikle ilk ikisinin himayesinde gelişen medeniyet için farklı olduğunu belirtir. Ptolemaios I. Soter (İ.Ö. 305-283)'in kültürel açıdan edebiyat ve bilime yardım ettiğini ve bu dönemde İskenderiye'nin kozmopolit kültürel bir cazibe merkezi olduğunu ve hatta bir dönem Atina'nın yerini almış olduğunu ifade eden Ballard (2013: 18), I. Ptolemaios'un isteği üzerine din adamı Manéthon tarafından Yunancaya çevirisi yapılan Mısır Tarihi eserinin bir çeviri

\footnotetext{
Samarya, veya Şomron Batı Şeria’nın kuzey kısmında yer alan dağlık bir bölge. Kitab-ı Mukaddes’in Türkçe çevirisinde bu yer adı Samiriye olarak verilmiştir.

Tanah'ın üç ana bölümünden ikincisi.

İran medeniyetinde ülke topraklarının ayrıldığı idari birimlere verilen ad.
} 
olarak kabul edilip edilemeyeceğini sorgular ve bunun bir ölçüde çeviri olarak kabul edilebileceğini zira bu otuz ciltlik eserin, en yüksek Antikiteden beri olayları anlatan bir derlemeyi temsil ettiğini ve yaşayanların gelenek ve dinlerini tasvir ettiğini belirtir. Ancak İ.Ö. 47 yllında İskenderiye Kütüphanesi yangınında bu eser ortadan kaybolmuştur.

Kraliyet sarayında diplomatik tercümanlar bulunduğunu ve bunların görevinin kralın kararlarını yabancı toplum ya da kabilelerden gelen temsilcilere iletmek olduğunu ifade eden Chrobak (2013: 93), eğer kraliyet görevlisi dili biliyorsa iletişimi kendisinin sağladığını ancak bilmediği durumda tercümana başvurduğunu, firavunlardan üçünün sarayında güçlü bir vezir olup daha sonra kendisi vezir olan (İ.Ö. 1333-1306) Horemheb'in bizzat tercümanlık yaptığını vurgulayarak, Eski Mısır'da rahip, yazman, asker ve çiftçiler gibi sınıflar hakkında çok bilgi bulunmasına rağmen tercümanlar hakkında çok fazla şey bilinmediğini vurgular.

Firavun Ptolemaios II Philadelphe (İ.Ö. 285-247) babasının kültür politikasını izlemiş ve Torah (Tevrat)'ın Yunancaya çevrilmesini sağlamıştır ki bunun arkasında iki neden bulunuyordu: entelektüel merak ve ihtiyaç (Ballard, 2013: 18). O dönem İskenderiye'de nüfusun yarısına yakınını oluşturan önemli bir Yahudi toplumunun bulunduğunu belirten Ballard (2013: 18), Yunancanın bu toplumun doğal dili olduğunu, Ptolemaios'un, Yahudi toplumunun beğenisini kazanma kaygısının yanı sıra dinî metinleri daha iyi tanıma isteğiyle Torah'ın çevrilmesi emrini verdiğini ifade eder.

\begin{abstract}
Aristeas Mektubu'nda (la Lettre d'Aristée) anlatılan bir efsaneye göre firavun II. Ptolemaios'un emri üzerine, erdemli ve saygin 72 bilgin Torah metnini 72 günde çevirecekti. 72 haham (her İsrail kabilesinden altı kişi) belirlendikten sonra, günümüzde Septante -yetmiş-kavramı anlam olarak, Eski Ahit'in İ.Ö. III. yüzyıldan I. yüzylla kadar çeşitli çevirmenler tarafindan Yunancaya gerçekleştirilen ilk çevirinin bütününü ifade etmektedir. Tarihçiler günümüzde bu yazının bir efsane olduğunu ve metnin birçok çevirinin sonucu olduğunu değerlendirmektedir. Eski Ahit'in diğer kitapları, Torah’ın çevirisini takip eden iki yüzyıl boyunca ve çeşitli çevirmenler tarafından çevrilmiştir. (...) Aramicenin gelişimi, İ.Ö. I. ve II. Yüzyıllarda bu dilde çevirilere yol açmıştır. 1947 yılında Kumran'da bulunan ünlü ‘Ölü Deniz ruloları’ Eski Ahit’in bu çevirilerinden bölümler ihtiva etmektedir. (Ballard, 2013: 18).
\end{abstract}

Ballard (2013: 19) Aristeas Mektubu'nda gerçekleştirilen çevirinin, her türlü değişikliğin yasaklanmasının öngörülmesi nedeniyle kesin bir metin olduğunu belirtir. Moatti (2006: 110), çeviri, göç ve iletişim üzerinde durduğu makalesinde, çevirinin sadece kültürel bir faaliyet olmayı aynı zamanda bir yönetim şekli olduğunu ve iki dilli bir imparatorlukta, merkez ve çevre arasında siyasî iletişimin bir yönünü yansıttığını belirterek, çevirinin başka açılardan göçle de ilişkili olup Aristeas Mektunu'nun, İncil'in Yunancaya çevrilmesini istediğini ve bunun için de Kudüs'ün en yüksek kademedeki papazından kendisine çevirmenler göndermesini istediğini dile getirir.

V. Ptolemaios (İ.Ö. 210-181) döneminden günümüze kalan ve şüphesiz Antik Dönemin en önemli çevirilerinden birini taşıyan Rosetta Taşı'dır. Daha büyük bir taş levhanın kırık bir parçası olan Rosetta Taşı’nın üzerinde bulunan yazı, kral Ptolemaios (İ.Ö. 204-181) ile ilgili resmî bir yazı içermekte ve 14 satırdan oluşmaktadır7. 1799 eylül'ünde Bonaparte ordusu tarafından tahkimat çalışmaları sırasında bulunmuş olan Rosetta Taşı üç adet yazı içermektedir: iki tür yazı (hiyeroglif ve demotik) ve bu metnin bir çevirisi.

https://blog.britishmuseum.org/everything-you-ever-wanted-to-know-about-the-rosetta-stone/ 


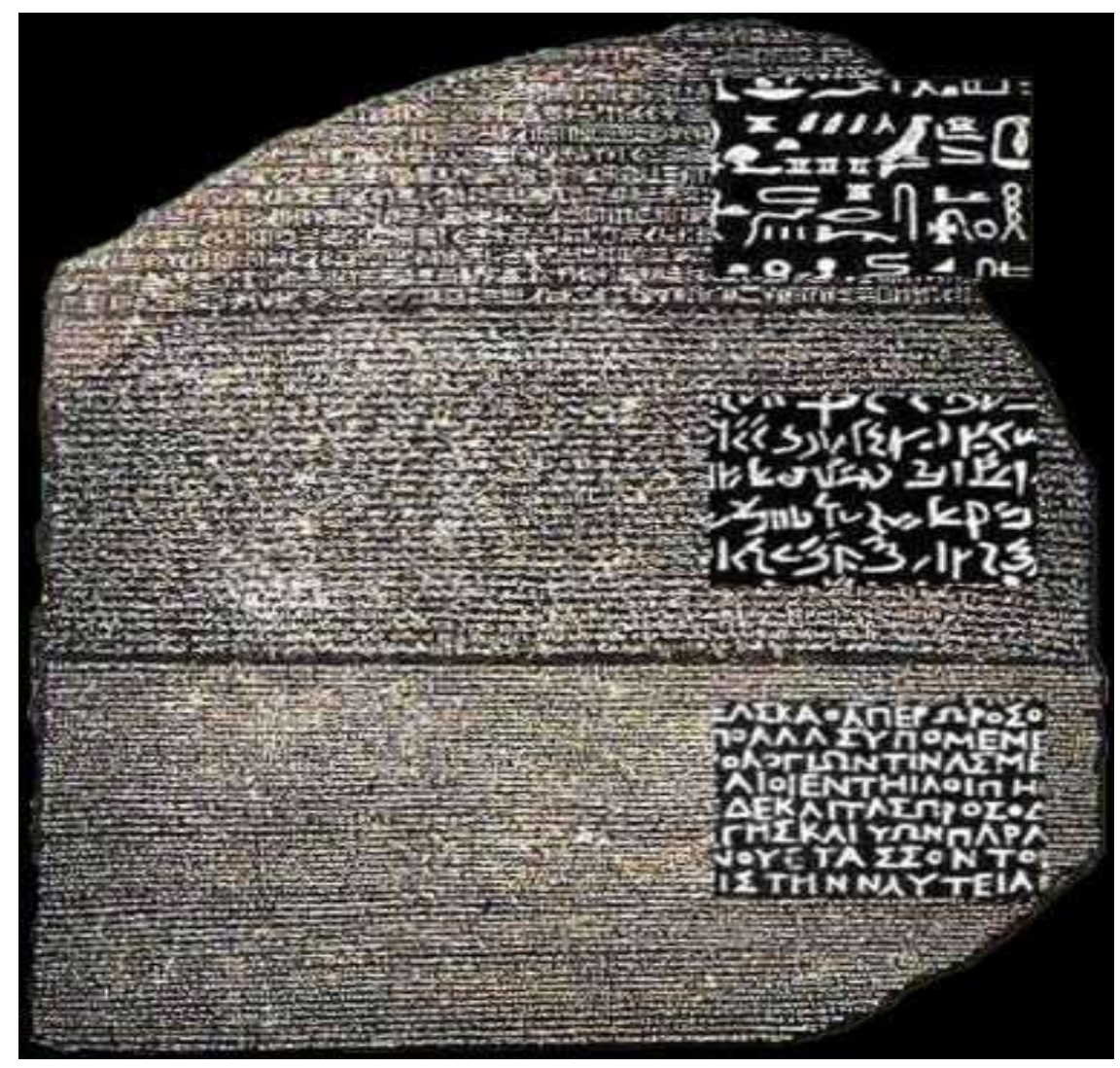

Rosetta taşı

Kaynak: https://www.pinterest.nz/pin/719942690415947783/

İ.Ö. 196 yllında V. Ptolemaios hakimiyeti döneminde gerçekleştirilen bu yazı, özet olarak 'Ptolemaios'un Mısır’ın tüm kanallarını tekrar açtırdığını ve bunun için önemli sayıda işçi istihdam ettiğini, önemli miktarda para harcadığını ve hükümdarlığının sekiz yılını geçirdiğini’ ifade etmektedir (Hartleben, 1983: 47-48; akt. Ballard, 2013: 20).

\section{Antik Roma'da çeviri faaliyetleri ve çevirinin kişiselleşmesi}

Çeviri tarihinin başlangıcı olarak kabul edilen Antik Roma döneminde, yeni bir çeviri bilincine ve çevirmenin belirleyici işlevine ilişkin bazı görüşlerin oluştuğunu ifade eden Yücel (2007: 32), Antik Yunanlılara ait birçok belge ve yapıtın çeviriler yoluyla günümüze kadar ulaştı̆̆ını dile getirir. Bartsch (2016: 30), Roma Dönemi edebiyatının çeviriye yöneldiğini, hem Romalıların hem de onlar hakkında yazan bilginlerin, Roma edebiyatının, Yunanca metinlerin sahiplenilmesi ve çevrilmesi yoluyla ortaya çıktığını dile getirdiklerini belirtir.

Günümüze kadar ulaşan uyarlama ve çeviri çalışmalarının üç özellik taşıdıklarını belirten Ballard (2013: 20), bunların çevirinin kişiselleşmesi, yadsınamaz bir kültürel hedefe sahip olması ve düşünce konusu olması olduklarını dile getirir. Romalıların başka bir kültüre, edebiyat dizgesine ait bir düşünceyi veya yapıtı kendilerine mal etme anlayışının çeviriye de yansıdığına işaret eden Yücel (2007: 34), bunun nedeninin, Romalıların uygulayıcı ve yararcı bir dünya görüşüne sahip olmalarından kaynaklandığını belirtir ve bunun sonucu olarak 'serbest' bir çeviri biçimi olarak adlandırılan bir yaklaşımın ağırlık kazandığını dile getirerek kaynak metne öykünmeye çalışmayan bu yaklaşımda daha önce olduğu gibi 
kaynak metindeki sözcüklerin odak olarak alınmadığını ve konunun erek dil dizgesi açısından ele alındığını belirtir ve bunun en belirgin kanıtının da ilk edebî metin çevirisi olan Livius Andronicus (İ.Ö. 284-205)'un İ.Ö. 240 yılında Yunancadan Latinceye çevirdiği Homeros'un Odysseia'sı olduğunu ifade eder.

\section{1. Çevirinin kişiselleşmesi : Livius Andronicus}

İmzalı ilk çevirilerin görüldüğü Roma döneminde, ismi bilinen, azat edilmiş Yunanlı bir köle olan ilk Avrupalı çevirmen Livius Andronicus (İ.Ö. 272-207), İ.Ö. 240 yılına doğru Odysseia’yı Latinceye çevirmiştir. Roma (Latin) edebiyat tarihi açısından önemli bir yere sahip olan ve doğum tarihi tam olarak bilinmeyen Livius Andronicus'un, İ.Ö. 284 yllında Güney İtalya'da yer alan ve 272 yllında Romalıların eline düşen Taras veya Tarentium'da doğduğu tahmin edilmektedir (Remains of Old Latin, 1936: ix). Doğumundan itibaren, şehir ele geçirildikten sonra, kalabalık bir Yunanlı köle grubuyla birlikte Roma’ya götürülen genç Andronikos'un görevi, tiyatro oyunları yazıp oynamak ve yaşadığı evin çocuklarına ve ailenin diğer bireylerine Latince ve Yunanca öğretmekti zira o dönemde öğretme görevi geleneksel olarak, Akdeniz havzasının doğu kısmında Yunancanın kültür ve iletişim dili olması nedeniyle aralarında belirli bir sayıda bulunan Yunanlı veya dillerini konuşan köleler veya azat olanlar tarafından yerine getirilirdi (Ballard, 2013: 20).

Dramatik eserler, bir millî marş ve Odysseia çevirisinin Livius Andronicus'a atfedildiğini belirten Weiss (2004: xiii), Odysseia'yı saturnius biçiminde çevirdiğini ancak kariyerinin hangi aşamasında ve hangi nedenlerle bu görevi üstlendiğinin bilinmediğini, Odysseia'nın ders kitabı amacıyla çevrildiği düşüncesinin de doğrudan bir Antik kanıtla desteklenmediğini ifade eder. Ancak Ballard (2013: 21), Odysseia'nın Yunanca ve Latince dillerinin öğretimi amacıyla bir el kitabı olarak çevrildiğini ve daha sonra da kullanıldığına işaret eder. Çeviri yoluyla kendi kültürüne yeni eserler kazandırma düşüncesinin bir sonucu olarak, Andronicus'un çevirisinde Roma döneminde egemen anlayışı yansıtan erek kültür dizge odaklı olan uyarlamacı bir yaklaşımın görüldügünü dile getiren Yücel (2007: 35), Antik dönemde kaynak metinlerin erek kültür dizgesine uyarlanmasının, çevrilen yapitların özgün olarak kabul edilmesine yol açtığını vurgular. Ballard (2013: 21), Andronicus'un Yunanlı olmaktan çok Romalı olduğunu, çevirilerinin de mükemmel bir Yunanca bilgisine sahip olmaktan uzak olduğunu ortaya koyduğunu zira çevirilerinde yanlış yorumlamalar bulunduğunu belirtir ancak Roma'ya destan, trajedi ve komedinin girmesini sağlaması nedeniyle övgüyü hak ettiğini dile getirir.

\subsection{Romen tiyatrosunun doğuşu ve çevirinin etkisi}

Romalıların, başka toplumların mirasındaki değerin farkına vararak bunları kendi amaçları için benimseyip adapte ettiklerine işaret eden Ochman (2013: 72), tanıştıkları Yunan medeniyeti zenginliklerinin kendileri için sonsuz bir ilham kaynă̆ olduğunu, çok yönlü olarak kültürel gelişimlerini harekete geçirdiğini ve Romen edebiyatının çeviri ile başladığını vurgular. Bu dönemden itibaren çeviri çalışması amacıyla olduğu kadar kişisel eserleri için de ilham kaynağı olarak Yunan kaynaklarından yararlanan Latin yazarlar olduğunu dile getiren Ballard (2013: 21), bu çeviri hareketinin oluşumunda birçok etkenin rol oynadığını belirtir ve bu etkenlerin, bir mirası aktarma kaygısının yanı sıra bazı kaynakların saygınlığından yararlanma arzusu olduğunu ancak buna ilave olarak yeni bir toplumun gereksinimlerinin ortaya çıması, Yunanistan'a karşı savaşlarda Romalı askerlerin, tiyatronun önemli bir yere sahip olduğu bu medeniyetin kültür ve eğlenceleri ile tanışması gibi nedenlerin sayılabileceğine dikkat çeker. 
Campania'lı hür doğmuş bir yurttaş olan ve hakkında çok fazla bilgi bulunmayan Gnaeus Naevius (İ.Ö. 269-199), hem komedi hem de trajediler yazan ilk Latin yazar olup, kariyerinin başından itibaren gözüpek ve açıksözlü bir şair olarak bilinirdi ve geride çok az değerli bölümleri kalan trajedileri ılımlı olarak bilinirdi ancak komedilerinde Aristophanes ve Atina'nın Eski Komedi'si (Old Comedy) ile rekabet etmişti (Stambusky, 1977: 29). Her ne kadar trajedi ve komediler yazmış olsa da biz Gnaeus Naevius'u çeviri açısından ele alacağız. Ballard (2013: 21), Gnaeus Naevius (İ.Ö. 270-201 ?)'un kişisel ilham ve dışarıdan kültürel aktarım paylaşımının temsilcisi olduğuna işaret ederek, birinci Kartaca Savaşı'na katılımını, Bellum Punicum (Kartaca Savaşı) adlı destanı için bir dayanak olarak kullandığını ancak günümüze bazı bölümleri kalmış olan Truva savaşından ilham alan trajediler çevirdiğini veya kaleme aldığını ifade eder.

Yunan asıllı olup Roma'da yaşayan Quintus Ennius (İ.Ö. 239-169), Horace tarafından 'ikinci Homeros' olarak adlandırılmış, Kartaca kuvvetlerine karşı Titus Manlius'un ordusunda hizmet etmiş, Roma soylularının çocuklarına Yunanca öğreterek hatırı sayılır bir para kazanmıştır (Dole, 1905: 15). İki dilli olan Ennius, Yunan kültürüne kendi çevresini öğretmiş, Roma tarihini anlattığı epik şiir tarzındaki kişisel eseri Annals (Tarihi Olaylar) dışında, çoğu Euripide'den uyarlama veya öykünme olan yirmi kadar trajedi yazmış diğer yandan da Euhemerus'un mitolojik romanı Histoire sacrée (İ.Ö. 3. Yüzyll sonu) adlı eserini şiirleştirmiştir.

Birçokları tarafından Roma komedi yazarlarının ilki ve en büyüğü kabul edilen Titus Maccius Plautus (ì.Ö. 254-184) Umbria'nın bir köyünde doğmuş, bir şekilde mükemmel Yunanca öğrenmiş, ancak Roma'ya geldiğinde çok zor durumda olması nedeniyle aktörlere hizmetçilik yapmış, kazandığı parayla firıncılık yapmış ancak bu işte başarısız olmuştur (Dole, 1905: 1). Popüler tiyatro için oyunlar yazan Plautus, Yunan yazarlar Menandros, Diphile ve Philemon'u taklit etmiş, en ünlü eserleri Amphytrion, La Marmite, Les Ménèchmes et Miles Gloriusus XVI ve XVII. yüzyıl yazarları için ilham kaynağı olmuştur (Ballard, 2013: 21).

Kartaca'da doğmuş olan Publius Terentius Afer (İ.Ö. 190-159), Roma'da senatör Terentius Lucanus'un kölesiydi ve iddia edildiğine göre yakışıklı biri olup efendisi kendisine özgürlüğünü bağışlamışı ve ona kendi adını vermişti (Augoustakis ve Traill, 2013: 1). Hür bir insan olarak eğitim alan Terentius, yüksek sosyete ve eğitimli çevrelerde dolaşmış, Plautus'a kıyasla, bu topluluk için daha edebî ve daha ağdalı bir dille tiyatro eserleri yazmıştır ve eserlerindeki entrika ve kişilerin isimleri Yunan olup, Menandros'tan ilham aldığında (örneğin, Adelphi), iki piyesi birinde birleştirir; Phormion için Apollodore de Charys’i kullanır ve İ.Ö. 160 yılında piyes aramak için Atina'ya gider ve bu yolculuk esnasında kaybolur (Ballard, 2013: 21).

$\mathrm{Bu}$ çeviri ve özellikle öykünme faaliyetinin, uygulayanların tanınması için olmadığına işaret eden Ballard (2013: 22), Romalıların İ.Ö. I. yüzyıla kadar özgün bir edebiyat meydana getirme konusunda yeteneksiz olmakla suçlanırken, Yunanlıların aksine model sağlama konusundaki yeteneklerine vurgu yapıldığını belirterek, Romalıların taklit yoluyla Yunanlılardan edebiyatı almalarının, el yazması alma faaliyetini katmerlediğine dikkat çeker.

İ.Ö. I. yüzyılda Sylla, Mithridate'a karşı savaşı sırasında (İ.Ö. 86), Aristo ve Theophraste'nin eserlerinin bulunduğu Apellicon de Téos kütüphanesini ele geçirmişti. Bu kütüphane Roma'ya götürüldü ve gramerci Tyrannion eserlerin büyük bir kısmına el koyarak, Rhodes'li Andronicus'a bir katalog oluşturmasını, özetleri yazmasını ve bildiğimiz külliyatı yayımlamasına izin verdi. Yunan tiyatrosundan esinlenen be çeviri ve uyarlamaların ardından, başka alanlarda da ürünler ortaya çıkmıştır. İ.Ö. I. yüzyılda, şair Matius İlyada'nın manzum çevirisini yaptı. Takip eden yüzyılda, şair ve hatip Silius Italicus (25-101), 75-80 tarihine doğru, Batıda henüz Yunancanın bilinmediği 
Ortaçağ'ın, Homeros'u dolaylı olarak tanımasına imkân verecek olan İlyada'nın Latince versiyonunu çevirecekti. Ayrıca Carthaginois Magon'un tarım üzerine otuz kitabı gibi Yunanca bilimsel eserler çevrilmiştir ki Gaius Plinius Secundus'a göre bu girişim Roma senatörü tarafından finanse edilmiştir. Ayrıca bunlara, Efes'li Soranos'un cerrahi incelemesi olan Le Gynecia adl eserinin Caelius Aurelianus ve Musto tarafindan II. yüzyılda Latinceye çevrildiğini ilave etmek gerekir. Nihayet imparator Augustus (İ.Ö. 63-14), İmparatorluğun ihtiyaçlarını karşılaması için bir çeviri bürosu kurdurmuştu (Ballard, 2013: 22).

\section{3. Çevirinin inceleme konusu olması}

McElduff (2013: 1), Romalıların İ.Ö. 3. yüzyıldan I. yüzyıla uzanan süreç içersinde fethettikleri toplumun kültürü üzerine, yani daha çok Yunan kültürü üzerine dayanarak bütün bir edebiyat meydana getirdiklerine ve hatta Yunanca bilgisini elit sınıfın temel bir unsuru haline getirdiklerine işaret ederek Yunanca konuşma, okuma ve çeviri yapmanın Roma elit sınıfın bir üyesi olmanın göstergesi haline geldiğine vurgu yapar. Dönemin en önemli siması Marcus Tillius Cicero (İ.Ö. 106-43)'nun Roma'nın en büyük hatibi olmasının yanı sıra Yunanca düşünce ve metinlerini Latinceye çeviren büyük bir çevirmen ve Roma'nın çeviri üzerine yazan en ünlü yazarı olduğunu belirten McElduff (2013: 1), onun çeviri kuramının, geniş bir kültürel tartışmanın bir parçası olarak görülmesi gerektiğine dikkat çeker.

Arpinum şehrinde çevresi geniş Romalı bir şövalye ailesinde doğan Cicero, İ.Ö. 90 yılında babası tarafından kardeşi Quintus ile birlikte eğitim için Roma'ya götürülmüş, ailesinin beklentilerinin ötesine geçerek cursus honorum (devlet görevi)'da ard arda devlet görevlerinde bulunmuş İ.Ö. 63 yllında konsolos olmuş, 63 yllından sonra konsolosluğu döneminde tartışmalı eylemleri nedeniyle kariyerinde iniş çıkışlar yaşamıştır (McElduff (2013: 1). Ballard (2013: 22), Cicero’nun yaşadığı dönemde Roma yüksek sosyetesinin iki dilli olduğunu, Cicero'nun da İtalya'da Yunanlıları incelediğini ve Atina, Smyrne ve Rodos'ta bulunduğu dönemde Ascalon'lu Antiochos, Zenon, Rutilius Rufus ve Apameia'lı Posidonios'un derslerini izlediğini belirterek Ksenofon'un Ekonomik ve Platon'un Protagoras eserlerini çevirdiğine vurgu yapar.

Cicero'nun kuramcılar tarafından genellikle serbest çeviri ile özdeşleştirildiğini belirten Yücel (2007: 46), çeviride 'ut interpre' (sözcüğü sözcügüne) ve 'ut orator' (serbest, anlama göre) bir ayrım yapmasının, onun çeviri tarihinde ilk kez kaynak metnin türüne göre bir çeviri yaklaşımı benimsediğini ifade eder. Du meilleur genre d'orateurs (İ.Ö. 46) (Hatiplerin En İyi Türü) adlı incelemesinde Cicero'nun çeviri konusuna değindiğini belirten Ballard (2013: 22), bu çevirinin bize ulaşmadığını ve Cicero'nun çevirisini yorumladığı metnin birkaç satırla sınırlı olduğunu, bazılarına göre de çeviri üzerine yazılmış, bilinen en eski ilk yazılardan biri olduğunu ifade eder ve Cicero'nun öneminin inkâr edilmez biçimde tarihî karakterinden, yazar kişiliğinden ve sözcüğü sözcüğüne değil, genel olarak anlamaya dayalı anlayışından ileri geldiğine işaret eder. Başka Latin yazarların da İ.Ö. I. ve II. yüzyıllarda çeviri üzerine açıklamalar yaptığına dikkat çeken Ballard (2013: 22), Cicero gibi Quintilien ve Genç Plinius'un, çevirinin şekil verici yönüne vurgu yaptıklarını, ancak Quintilien'in bu konuda, dillerin doğasının farklı olması nedeniyle gerçekçi bir görüşe sahip olduğunu, öte yandan Plinius'un ise, çeviri yaparken anlamın derinine inilmesi ve daha hassas bir anlamaya ulaşılması gerektiğine işaret ettiğini dile getirir. AulusGellius, Nuits attiques adlı eserinde, dilbilimsel, üslup ve hatta ahlaki düzene bağlı nedenlerden dolayı serbest bir çeviri anlayışını savunur (Ballard, 2013: 22).

\section{Hıristiyan dünyası: çevirinin odak merkezi}

Hıristiyan dünyasında İncil çevirileri özel bir yer tutmaktadır. Doğrudan Hz. İsa tarafından yazılmış metinlerin kalmadığını belirten Ballard (2013: 23), Hz. İsa'nın öğretilerinin sözlü olarak iletildiğini ve 
ancak birinci yüzyılın ikinci yarısında yazılı hale getirildiğini, çoğunluğu V. yüzyıla tarihlenen binlerce el yazmasının bulunduğunu ve bazılarının da müstensih (kopyacı) hatalarıla dolu varyantlarının bulunduğuna dikkat çeker.

\begin{abstract}
İlk metinler rulolar üzerine yazılmıştır; II. yüzyıldan itibaren bir kodeks (kitap) oluşturan sayfalar kullanılacaktır. Uzun süre en eski ve en güvenilir kabul edilen metinler Vatikan Kütüphanesi’nde muhafaza edilen Codex Vaticanus ve IV. yüzyılın başlarına tarihlenmiş olup British Museum'da muhafaza edilen Codex Sinaiticus'tur. XX. Yüzyılda, II. Yüzyıla tarihlenmiș kodeks (kitap) ve papiruslar bulunmuştur. Aramca verilmiş sözlü derslerden hareketle Yunanca yazılmış olan İnciller, Yeni Ahit’in sadece bir kısmını oluşturmaktadır. Yeni Ahit, bir bütünlük oluşturan 27 kitaptan oluşmaktadır: İnciller, Mektuplar, Havari Belgeleri, Kıyamet. Hz. İsa'nın Aramca konuştuğu ve bu dilde vaaz ettiğine inanmak için her neden mevcuttur. Halbuki İnciller Yunanca yazılmıştır (belki Mathieu İncilinde İbranice) ve bazıları, Aramca sözlü olarak verilmiş olan bu derslerin kopyalarının bir çeviri formu oluşturduğuna inanmaktadır. Bu durumda Evanjelistler (İncil yazarları) ilk Hıristiyan çevirmenlerdir. Birçok tür çalışma, az ya da çok doğrudan çeviri ile alâkalı Kutsal Kitaplar etrafinda gelişmiştir. (Ballard, 2013: 23).
\end{abstract}

\title{
7.1. Tatian ve Diatessaron
}

Doğu Suriyeli olup 120 yllına doğru doğmuş olan Tatian, geldiği Roma'da Justin’in derslerini takip eder ve 172 yılında ülkesine dönmeden önce onun etkisiyle Hıristiyan olur. Tatian'ın özelliği, kesintisiz bir anlatı oluşacak şekilde kaynaştırdığı dört İncil'in yapay bir versiyonu olan Diatessaron'u derlemek olmuştur ancak tefsir edenler, bu kitapta dogma açısından tehlikeli çarpıklıklar olduğunu ortaya koymuştur (Ballard, 2013: 23). Schaff (2010) Diatessaron'un öylesine kişiler üstü bir çalışma olduğunu belirterek kimin derlediğini bilmeye gereksinim olmadığını dile getirir ve Tatian'nın Süryani topraklarında doğduğunu ve kâfirliği getirdiğini belirterek, bilgi peşinde koşarak Roma'ya yerleştiğini, burada Martyr Justin’in öğrencisi olup Hiristiyan olduğunu ifade eder ve Justin’in ölümünden sonra Mezopotamya'ya geri döndüğünü, muhtemelen burada, Süryani kilisesinin kalbinde sıcak bir yer tutan ve Süryanice en önemli eseri olan Diatessaron'u yayınladığını ifade eder, ancak diğer yandan Tatian'ın Yunanlı bilginler arasında heretik (sapkın), çileci ve Gnostik ${ }^{8}$ olarak kabul edildiğini dile getirir. 9 Diatessaron, Yunanca kaleme alınmış bir parça olarak ulaşmış ve Suriye'nin Dura Europos ${ }^{10}$ şehrinde bulunmuş olup bu çalışmanın orijinalinin Yunanca metin veya Süryanice kaleme alınmış bir versiyonu olup olmadığı ve ayrıca bu sentez çalışmanın ne zamanı ne de nerede gerçekleştirildiği bilinmemektedir (Ballard, 2013: 23).

\subsection{Origen ve Hexapla}

185 yllına doğru İskenderiye'de Hıristiyan bir ailede doğan Origen, gramer öğretirken Piskopos Demetrios tarafından kendisine kateşetik (soru cevap usûlüne ait) okulunun sorumluğu verilir. Çeşitli sıkıntılardan (Roma, Kayseyra"11 İskenderiye, Yunanistan) sonra 230 yılında Kayseyra'ya yerleşir ve burada tefsir öğretir ve tefsir üzerine çalışmalar yapar ve bu nedenle karşılaştırmalı yöntemin kurucularından biri olarak kabul edilebilir. Önce kutsal kitaplara, İskenderiyeli bilginlerin metin eleştirisi ilkelerini kutsal metnin çeşitli çevirilerini yan yana koyarak uygulamayı planlar. Burada söz konusu olan, İbranice karakterle yazılmış Eski Ahit’in İbranice metni, Yunan harfleriyle yazılmış kopyası ve Aquila, Symmachus, Septante ve Theodotion'un Yunanca çevirilerinin altı sütuna yerleştirildiği Hexapla'dır. Altı bin beş yüz sayfalık bu metnin sadece bazı parçaları kalmıştır. Kutsal kitabın inanç

Sezgi veya tefekkür yoluyla edinilen bilgiye inanan kişi.

http://www.ccel.org/ccel/schaff/anfog.html

Dura Europos Kilise Evi, günümüze arkeolojik olarak buluntuları ulaşan bilinen en eski kilisedir.İsa'dan sonra 232/233 yıllarına tarihlenen kilise evi, Fırat nehri kıyısındaki Dura Europos şehrinde bulunmuştur.

İsrail'de bir şehir. 
kaynağı olması nedeniyle, Origen hemen hemen tüm kutsal kitaplarla ilgili yorumlar yazmış ve bunların çoğu, günümüze Latince çevirisi ile ulaşmıştır (Ballard, 2013: 23).

Orlinsky (1936: 137), İskenderiye ve Mısır’n diğer merkezlerindeki Yahudilerin ana dillerini unutmuş olmalarından dolayı daha İ.Ö. üçüncü yüzyılda İncil’i orijinalinden okuyup inceleyemediklerini ve bir sonraki yüzyll veya sonrasında Eski Ahit’in Yunanca çevirisi Septuagint'in onlar için yapıldı̆̆ını, önceki nesillerin İbranice orijinalini okuduğu gibi araştırma ve dualarında Septuagint’i kullandıklarını belirtir. Yahudilerin kutsal metni anlama konusunda yaşadıkları sıkıntılara çözüm bulmayı kendine görev edinen Origen Hexapla’yı kaleme alır. Hexapla diğerleri arasında ders kitabı açısından son derece kullanışlıdır: Birinci sütun İbranice karakterlerle yazılmış metni içerir; ikinci sütun okuyucuya İbranice nasıl telaffuz edileceğini öğretir; Aquila'nın çevirisi sadece, orijnaline çok benzeyen sözcüğü sözcüğüne hatta harfi harfine 'orijinalinin her bölümünün Yunanca veya yarı Yunanca eşdeğerini vermekle kalmaz aynı zamanda etimolojisini de verir; Symmacus çevirisi ise anlaşılmayan Aquila Yunancasının normal Yunanca çevirisi olarak gerekli bir metindir; ve ilk dört sütundan elde ettiği bilgiyle donanmış olan okuyucu, en önemli sütunla, yani Septuagint’i (V. sütun) çözmeye hazırdır; VI. sütunda yer alan Theodotion, Aquila ve Symmachus çevirilerinden üstün bir yerdedir ve Origen tarafından beşinci sütunu gözden geçirerek düzeltmek için kullanılmıştır (Orlinsky, 1936: 146-147). Orlinsky (1936: 149)'ye göre Hexapla'nın oluşumunun arkasında yatan neden, Origen'in, döneminin Hıristiyanlarına İbrani dilini öğrenmek için bir ders kitabı sağlamaktır.

\subsection{Vetus Latina}

Vetus Latina, St Jerome’un Vulgata'sının Latince konuşan Batılı Hıristiyanlar için standart İncil olmadan önce çevirisi yapılan Latince İncil metinlerine verilen ortak bir isim olup Vetus Latina ifadesi Eski Latince yerine kullanılır ve bazen Eski Latince İncil olarak bilinir.

Havari Paul'ün sağlığında Roma'da bir Hıristiyan cemaati bulunduğunu ve yeni dini dışarıdan getirenlerin ve ilk inananların Doğudan geldiklerini ve Yunanca konuştuklarını belirten Ballard (2013: 24), bu dilin bir asırdan fazla Hıristiyanların dili (Süryani ve Kıptîler hariç) olduğunu, Yunancanın Roma imparatorluğu döneminde ayrıcalıklı bir konuma sahip olup bir kültür dili olduğunu ve ayrıca tüm Akdeniz havzasında ticaret ve seyahatlerde de kullanıldığını, II. yüzyılın sonunda Batı Kilisesi açısından bir şeylerin değiştĭği, popüler tabanının gelişip Latince vaaz verilmeye başlandığını ve İncil çevirilerinin de dahil olduğu Latince bir literatür oluştuğunu ifade eder.

Latincenin Galya ve Kuzey Afrika'da hakim olması nedeniyle Latince İncil çevirilerine ihtiyaç ortaya çıkarmıștır. Tertullianus'un ${ }^{12}$ Latince İncili tamamen veya kısmen kullanmış olduğu bilinmektedir. Eski çeviriler Septante'den itibaren ve aslına sadık kalma ilkesine göre yapılmıştır. Vetus Latina veya Vetus Itala tek bir çalışma olmaktan çok bölük pörçük çevirilerin bütününü ifade eden ortak bir çalışmadır. Birçok çeviri bulunmaktadır: Avrupa veya İtalyan, Afrika veya bir İspanyol. Bu çeviriler II. yüzyıldan III. yüzyılın ortalarına kadar gerçekleştirilmiştir. Aslına sadık kalma ilkesinin ötesinde, büyük klasik yazarların söz (ancak putperest) sanatının aksine, üsluba bakmadan halk dilinde, bir mesajın doğrudan ve hazırlıksız olarak doğruluğuna ulaşılabilmesi ve okunabilmesinin bir teminatı olan ifade sadeliğiyle yazılmıştır (Ballard, 2013: 24).

Tek bir Vetus Latina İncili olmayıp St Jerome'dan önce İncil pasajlarının Latince çevirilerine tanıklık eden İncil el yazma metinleri koleksiyonu vardı ve birçok bilgin, Latin papazların çalışmalarında

12 İ.S. $160-225$ yılları arasında yaşamış kilise babası. 
görünen İncil pasaj çevirilerine sık sık ilaveler yapıyordu ve böylece birçok Vetus Latina çevirisi, tüm Kilisede kullanılan İncil çevirileri gibi kendi düzeni içinde yayınlanmıyor daha çok Vetus Latina’nın

bölümlerini oluşturan metinlerin birçoğu Hıristiyan toplumunun yerel kullanımı için veya hazırlanmış diğer Hıristiyan söyleminin veya vaazının aydınlatılması amacıyla hazırlanmıştı. Eski Latince çevirilerin dili kalite açısından düzensiz olup çok sayıda dilbilgisi hataları bulunmaktaydı. Bazı Yunanca veya İbranice deyimler, Septuagint'te olduğu gibi sözcüğü sözcüğüne kopyalanıordu ve İbranice orijinallerinden çok bu Yunanca çeviri, Eski Ahit'in Eski Latince çevirilerin hepsi için kaynak olmuştur ${ }^{13}$.

\subsection{Doğu çevirileri}

Hıristiyanlığın yayılışı, kutsal çevirilerin II. yüzyıldan itibaren Kıptîce çeviriler, Septante'den itibaren IV. yüzyıldan VII. yüzyıla kadar gerçekleştirilen Etiyopya dilinde çeviriler ve Süryanice çeviriler gibi çeşitli dillere yapılan çeviriler şeklinde kendini göstermiştir ki Süryanice çeviriler için Peshitta örneği verilebilir (Ballard, 2013: 24). Peshitta, hem İbranîce metne dayanarak II. yüzyılda yapılan Eski Ahit çevirisi hem de 400 ylları civarında standart çeviri haline gelen Yeni Ahit'in Eski Süryanice çevirisinin gözden geçirilmiş şekline verilen isimdir. Çağdaş bilim adamları Peshitta çevirmeninin bilinmediği konusunda hemfikirdir ${ }^{14}$. Bloch (1919: 215-222), Peshitta çevirmeni konusunun İncil konusunda çalş̧an bilim adamlarını hâlâ meşgul ettiğini, ancak birçok çevirmenin ortak eseri olmasına rağmen kaynağının Yahudiler mi yoksa Hıristiyanlar mı ya da her ikisi de mi olduğu konusunda ihtilaf içinde olduklarına dikkat çeker.

407-414 ylları arasında papaz ve keşiş Mashtotz tarafından gerçekleştirilen Ermenice çevirinin, sadece sözlü dili olan bir dilin alfabesinin oluşmasına yol açtığını ifade eden Ballard (2013: 24), aynı zamanda Mesrop Machtotz olarak yazllan Mashtotz (360-441)'un, Yunanca ve Süryanice metinlerden hareketle Catholicos Sahek ve çeşitli ortaklarla birlikte çalıştığını ve Paul (2007: 160)'den aktararak, Kutsal Kitabın Ermenice çevirisinin her zaman sözcüğü sözcüğüne olmadığını, yorum ve uyarlama unsurlarının çok olduğunu belirtir.

\subsection{Ulfila ve Ariusçuluk}

Ariusçuluk ya da Arianizm, 4. yüzyılda İskenderiye'de yaşamış olan Arius'un geliştirdiği kuramsal öğreti olup en tartışmalı tarafı, Hıristiyanlıktaki Baba-Oğul ilişkisiyle ilgilidir. Ortodoks Hıristiyanlığa göre İsa, Tanrı Baba'nın oğlu ve oğlu Tanrı Baba gibi gerçek tanrıdır. Oysa Arius ve taraftarlarına göre İsa ancak ikinci derecede ve bağımlılığı olan bir tanrılı̆̆ı haiz olup İsa, başlangıcı olmayan, sonsuz ve her şeye gücü yeten gerçek tanrı değildiri5. Ballard (2013: 24-25), Ariusçuluk ya da Aryanizmin 320 yllından itibaren İskenderiyeli Arius (280-336) isimli bir din adamı tarafından vaaz edilen bir doktrin olduğunu, Teslis dogmasını eleştirdiğini ve Hz. İsa'nın tanrısallığını inkâr ettiğini belirterek, Arius'a göre Hz. İsa'nın şüphesiz istisnaî bir varlık olduğunu ancak tanrı olmayıp bir "yaratılmış" olduğunu ifade eder. Bu doktrin birçok din adamını mahcup etmiş ve 325 yılında İznik’te Konstantin tarafından toplanan konsil Arius teorisini yasaklayarak son derece kesin bir inanç bildirisi kaleme almıştır: "İsa doğmuştur, yaratılmamıştır" (Hammel \& Ladrière, 1991: 30; akt. Ballard, 2013: 25). Ballard (2013: 25)'ın belirtiğine göre bu resmî pozisyon alış konuyu sonuçlandırmaz, imparatorluğun Batısı genel olarak konsilin

http://www.fact-index.com/v/ve/vetus_latina.html

https://gedsh.bethmardutho.org/Peshitta

https://tr.wikipedia.org/wiki/Arius\%C3\%A7uluk 
kararına katılırken Doğu tarafı Ariusçuluğu benimseme eğilimi gösterir ki piskopos Ulfila’nın 341 yılından itibaren Gotlara öğütlediği sapkınlık budur.

Ulfila (veya Ulfilas ya da Wulfila; yaklaşık 310-383) ${ }^{16}$ kardinal, misyoner ve Kitab-ı Mukaddes tercümanı olup Got ya da yarı Got ve yarı Yunan bir Kapadokyalıdır. Arian ihtilafının en sıcak zamanlarında Roma'da yaşamış olan Ulfila, İzmitli Eusebius tarafından atanmış ve kendi insanlarına misyonerlik yapmak için geri dönmüştür. Ebbinghaus (1991: 236-238), Got piskoposun isminin doğru şeklinin Ulfila(s) mı yoksa Wulfila mı olduğu konusunda bir uzlaşma olmadığını belirterek, Ulfila’nın, inancının bildirisini yazdığını veya yazdırdığına vurgu yapar. Ulfila isminin Got dilinde Wulfila (küçük kurt) anlamına geldiğini ancak bunun sadece bir varsayım olduğunu ifade eden Ballard (2013: 25), Ulfila'nın 311 yılına doğru vizigot bir babadan ve Kapadokyalı bir anneden doğduğunu ve 340 yllına doğru Constantinople piskoposu ve Arius yanlısı Nicomedia'lı Eusebius (280-341) tarafından piskopos olarak kutsandığını, Eusebius'un İznik konsilinden (325) sonra Licinius'un suç ortağı olmasından dolayı sürgüne gönderildiğini ve 328 yllında tekrar çă̆rıldığında Arianların başına geçtiğini ifade eder.

Ulfila tarafından yürütülen din değiştirme çalışması İncil'i çevirme girişimine neden olmuştur. Frauzel (1984: 98), Ulfila'nın muhtemelen yarı Got yarı Kapadokyalı olduğunu ve Yunanca konuşan ve Hıristiyan olan büyükbabasının, Ulfila'nın doğumundan elli yll önce Gotlar tarafından mahkum edildiğini belirterek, kendisini piskoposluğa götüren kilise eğitiminin akıcı bir Yunanca öğrenmesine neden olduğuna işaret eder. Ulfila İncil çevirisi için, sadece sözlü biçimi olan Got dilini yazabilmek amacıyla bir alfabe oluşturmak zorunda kalmış, bunun için de Yunanca alfabeyi temel almış ve buna Alman ve İskandinav alfabelerinin ilk biçimlerini temsil eden Runik ve Latince unsurlar ilave etmiştir (Ballard, 2013: 25). Ulfila çevirisinin Yunanca metinden hareketle gerçekleştirildiğini ve sözdizimine sıkı bir şekilde bağlı kalındığını ifade eden Ballard (2013: 25), ahlâkî amaçlarla ilginç bir sansür ortaya koyulduğunu, Gotların savaşçı düşüncesini teşvik etmemek amacıyla Ulfila'nın, sayısız savaş hikâyesi içeren Le Livre des Rois (Krallar Kitabı)'nı çevirmediğini belirtir.

\subsection{Hieronymus ve çalışmaları}

Latince Eusebius Hieronymus olarak bilinen Saint Jerome, çeviri tarihini etkilemiş önemli bir kişiliktir. Kültürlü bir kişiliğe sahip olan Saint Jerome, klasik pagan edebiyatını biliyordu ve ayrıca ilahiyat ve dil eğitimi almıştı. Önemli miktarda dinî metin çevirmiş veya çevirtmiş, çeviri konusundaki düşüncelerini önsözlerde ve ünlü bir mektupta açıklamıştır. 347 yllında Dalmaçya (bugünkü doğu Hırvatistan)'nın Stridon şehrinde hali vakti yerinde toprak sahibi bir ailede doğmuş olan Hieronymus, çağdaşları Saint Ambroise ve Saint Augustin ile birlikte dördüncü ve beşinci yüzyllarda Latin kilisesinin eşsiz triumvirliğini oluşturmuştur (Ballard, 2013: 25; Largent, 1900: vıl). Kariyerinin büyük bir kısmı I. Théodose döneminde geçmiş olan Hironymus, Roma'da aldığı klasik eğitim sonrası yönetimde görev almayı tasarlar ancak önemli ruhsal bir kriz, hayatını İsa'ya adamaya sürükler ve 373-374 yllarında Doğu'ya gidip manastır hayatı yaşamaya ve ilahiyat konusunda bilgisini derinleştirmeye karar verir. 379-382 yllları arasında Nazianze'lı Grégoire'ın derslerini izlediği ve daha sonra arkadaş olduğu Konstantinopolis'te kalır. Hieronymus'un Yunanca bilmesi ve bu dilde metinleri okumasının, kendisini bu metinleri yayma ve çevirmeye yönelttiğini belirten Ballard (2013: 25), Yunan ve İbranîlerle ilgili bilgileri bir araya getiren ve Konstantin hakimiyetine kadar olan dönemi kapsayan ve bir tür Antik dönem tarihi olan Eusèbe de Césarée Kroniğinni Latinceye çevirdiğini vurgular.

\footnotetext{
$16 \quad$ https://tr.wikipedia.org/wiki/Ulfilas
} 
Papa I. Damase (366-384) 382 yılında Roma'da bir konsil toplanması çağrısında bulunur. Konsiledavet edilen Jerome, oraya Antioche ve Salamine piskoposları ile birlikte gider ve burada onlara tercümanlık yapar. Jerome Roma'ya vardığında, daha önceden yorumcu ve kültürlü biri olarak ün sahibiydi. Damase 382 yllında Jerome’u sekreter olarak görevlendirir ve papalık arşivlerinin ve kütüphanesinin yönetimini kendisine verir, zira Damase Roma Saint Laurent bazilikasında VII. yüzyllda Latran'a transfer edilen bir kütüphane kurmuştu. Daha sonra Damase kendisine Vetus Latina'dan hareketle Latince bir metin oluş̧urması görevi verir.(...) Jerome, papaya İncillerin gözden geçirilmiş bir çevirisini sunar ancak 384 yılında hayatını kaybeder. (Ballard, 2013: 26).

Largent (1900: 26), Yunanca yazılmış olan İncillerin, Batılı Hıristiyanların kullanması için erkenden Latinceye çevrilmiş olması ve ilk çevirisinin elyazmalarında düzeltmeler ve ayrıca sayısız değişiklik ve eklemeler bulunması nedeniyle Damase'ın Jerome'dan hem uyum sağlanması hem de bütün bir İncil örneğinin oluşturulması amacıyla, Yeni Ahit’i Yunanca orijinaline göre gözden geçirmesini istediğini belirtir ve Jerome'un, papanın desteğiyle kendisinden istenen çalışmayı sonuçlandırdığını, çalışma esnasında metinde yapılan değişiklikleri çıkardığını, yanlış çevirileri ve diğer hataları düzelttiğini dile getirir. Ancak Ballard (2013: 26), Jerome ile birlikte Hıristiyan Batının yeniden çeviri ve özellikle de yeniden çeviri skandalı ile karşılaştığını dile getirerek, bu konudaki tepkinin iki zaman ve iki şekilde ortaya çıktığını belirtir: Yeni Ahit'in Yunanca metinlerden hareketle yürütülen yeniden çevirisi toplum tarafından iyi karşılanmamıştır zira alışılmış olan metinle birlikte oluşan geleneği koparmış, özellikle Saint Augustin tarafindan tepkiyle karşılanmıştır.

Eski Ahit açısından bakıldığında, Jerome'un Orta Çağ'da tamamladığı çalışma dikkat çekicidir ve hümanist bir girişim ortaya koymuştur: En eski metinlere dönüş, İbranice öğrenimi, Hexaples metinleri ile yüzleşme, Yahudi doktorlarla birlikte yorum. Jerome’a göre yeniden çeviri karşılaştırma temelinden doğar; etik bir amacın sonucudur; rahatsız edici sonucu, Septante'yi tartışlmaz bir metin olarak kabul eden Saint Augustin gibi bir otorite tarafından kuşkulu bir tepki ortaya konmuştur; bu nedenle Jerome'a, kendisinden önce gelen daha ihtiyatlı çevirmenlere kendisini inandırma riski taşıyan gururunu yenmesini tavsiye eder. (Ballard, 2013: 26-27).

Hieronymus (395), aynı zamanda Saint Augustin’in arkadaşı Romalı senatör Pammachius’a yazdığı ve De optimo genere interpretandi (en iyi çeviri yöntemi) başlı̆̆ını kullandığı mektubunda çeviri yönteminden söz eder ve sözcük sırasının bir sır olduğu kutsal kitaplar hariç, Yunanca çevirilerde sözcüğü sözcüğüne değil, anlamı aktardığını dile getirir. Yücel (2016: 60) de Hieronymus'un, Cicero'dan etkilenerek dünyevî metinlerin çevirisinde anlamın belirleyici olduğunu savunduğunu ve bundan dolayı da dünyevî çevirilerde erek kültür odaklı düşündüğünü belirterek, Tanrı tarafından yazdırılmış olmaları nedeniyle kutsal metinlerde, içeriğin yanı sıra o dilin bir parçası olan söz diziminin kutsal sayılması gerektiğini düşündüğünü ifade eder. Hieronymus'un mektubunun çeviribilim açısından kurucu bir niteliğe sahip olduğunu belirten Ballard (2013: 28), Yunancadan Latinceye çeviride metnin dışına çıkarak gerçekleri yansıtmadığı suçlamalarına getirdiği savunmasının, olayın çerçevesinin dışına çıkarak türüne göre çeviri şeklini bir araya getiren görüşlerini ortaya koyduğuna işaret eder.

Yazılarının bazılarının ölümünden sonra çevirilerinin önsözlerine koyulduğu düşünülmektedir. Önsözleri, Pammachius'a yazdığı mektubunda kutsal metinler için belirtilen görüşten farklı bir çeviri anlayışı ortaya konduğunu ortaya koyar: Job kitabının girişinde bazen sözcükleri, bazen anlamı bazen her ikisini de aktardığını ifade eder. Pammachius'a yazdığı mektubunda kutsal kitap çevirisinin sözcüğü sözcüğüne olması gerektiğini düşündüğünü belirtse de uygulamada temel ilkesinin, kaynak metnin sözcüklerini değil, anlamını aktarmak olduğunu ifade eder. Bir dildeki deyimlerin diğer dilde karşılığ olmadığı durumda, anlamı değiştirmediği sürece Latincenin zarafetini koruma hakkına sahip olduğunu düşünüyordu. (...) Çevirisini hiçbir zaman bireysel tarzına göre yapmamış, çok beğenmediği İbranice renkleri yansıtan kilise Latincesini dikkate almıştır. Geleneğe uymak zorunda olduğunu dile getiriyordu. Daha kuramsal bir düzeyde, diğer Hıristiyan entelektüeller gibi düşünüyor ve Kutsal Kitap’ta önemli olanın edebî biçim değil, içerik olduğunu söylüyordu. (Ballard, 2013: 28). 
Translation actvities in the Antique Age: A study on the characteristics of the translations and the situation of the translators / R. Hatipoğlu (pp. 1258-1280)

Al-Ali ve Majid (2015: 49-74), Hieronymus'un çeviri alanındaki en önemli katkısının 'sözcüğü sözcüğüne' ve 'anlamına göre' kavramlarını getirmesi olduğunu belirterek, Pammachius'a yazmış olduğu 'On the Best Method of Translation' başlıklı mektupta (57. Mektup), bu kavramlara değindiğini, çevirmenlerin çeviri esnasında karşllaştıkları zorluklar ile Eski ve Yeni Ahit (Vulgate)'in Latince çevirilerinin arkasında yatan sebepleri nasıl desteklediğini açıkladığını dile getirir.

\subsection{Roma imparatorluğunun sonu}

Konstantinopolis şehrinin kurulmasıyla Roma İmparatorluğu'nun doğu ve batı merkezli bir imparatorluk haline geldiğini belirten Çapan ve Güvenç (2017: 638), başlangıçta siyaseten ve hukuken birbirine bağlı olan doğu ve batının zamanla birbirinden ayrılma eğilimine girdiğini, zira I. Theodosius'un kendi hanedanlığını kurmak düşüncesiyle ölmeden önce imparatorluk topraklarını oğulları arasında taksim etmesinin imparatorluğu giderek içinden çıkılmaz bir hale soktuğunu ifade eder.

Batı Roma İmparatorluğu’nun son döneminde dinî hayat konusunda Ballard (2013: 29) şunları söyler:

III. Yüzyılın başında Diocletianus döneminde baskıya maruz kalan Hıristiyanlar, Konstantin döneminde hâlâ bir azınlıktı. Hıristiyanlık, yönetici sınıfın dini olarak, paganizm karşısında önemli bir çekim gücü olmuș ve uzun süre yaygınlığını sürdürmüștür. Bununla birlikte, imparatorun dinî açıdan karışması, 379 yılında tahta çıkan I. Theodosius döneminde kendini daha fazla göstermiş ve sadece sapkınlara karşı değil paganizme karşı da bir mücadele başlatmıştır. Bu bağlamda kehanetlerin yasaklanması gibi bir dizi önlem alınacaktır. 391 yılında I. Theodosius, imparatorluğun bütün putperest tapınaklarının kapatılması için kararname çıkarır; eski Mısır dini bağlıları artık sayıca fazla değildi ancak bu tedbir daha büyük bir hoşnutsuzluğa yol açacak ve Mısır hiyeroglif yazısıyla temasın kaybolmasına neden olacaktır. Bu yazı, din adamları tarafindan aktarılmıştı; dinlerini etkileyen bu yasaklama daha sonra fizîken ortadan kaybolmaları, hiç kimsenin hiyeroglifleri okuyamaması sonucunu ortaya koymuştur. Böylece V. yüzyılın ortasından itibaren bu işaretler yardımıyla yazılan metinler anlaşılmaz hale gelir ve Rosetta taşının ortaya çıkarıldığı ve Champollion tarafından çözümlenip okunur hale geldiği XIX. yüzyıla kadar bu şekilde kahır.

Theodosius 395 yılında imparatorluğu iki oğlu arasında bölüştürür: küçük oğlu Honorius Roma'da, büyük oğlu da Konstantinopolis’te kalır. Bu resmî bölüşümle birlikte imparatorluk birçok bölünmeye ve çok kutuplu yönetimlere maruz kahır.

\section{Antik Dönemde çevirilerin niteliği ve çevirmenin konumu}

Tarihten günümüze her dönemde çeşitli alanlarda çeviriler yapılmış ve bu faaliyetler dönemin şartlarına göre bazen diplomatik, askerî ve ticarî alanlarda, bazen dinî konularda ve bazen de edebî konularda ağırlık kazanmıştır. Ancak tarihte çevirinin yapılmadığı hiçbir dönem olmamış, bazen çeviri konularında dönemin ihtiyaçlarına göre belirli alanlar daha çok önem kazanmıştır. Çevirmenin, toplumda çok önemli bir konuma sahip olduğu dönemler olmuş, bazen de tamamen geri planda kaldı̆̆ı dönemler de olmuştur. Aşağıdaki tabloda Antikçağda (veya İlkçağda) çevirilerin ağırlıklı olarak yapıldığı alanlar ve çevirmenin konumu ile ilgili bilgiler verilmiştir.

Tablo 1. Antikçağda çevirilerin niteliği ve çevirmenin konumuna ilişkin bilgiler

\begin{tabular}{|l|l|l|}
\hline Dönem & Çeviri alanları & Çevirmenin konumu \\
\hline $\begin{array}{l}\text { Eski Mısır (̇̇.Ö. 300o- } \\
\text { I.Ö.332) }\end{array}$ & $\begin{array}{l}\text { Diplomatik, ticarî ve askerî faaliyetler; } \\
\text { büyük güçlerle yapılan anlaşmalar. }\end{array}$ & $\begin{array}{l}\text { Hem tercüman hem de diplomat; yedi } \\
\text { sosyal sınıftan birini oluşturmakta. }\end{array}$ \\
\hline Mezopotamya & $\begin{array}{l}\text { Diplomatik ve ticarî faaliyetler; dinî } \\
\text { konular (Yahudilerin esaretini anlatan }\end{array}$ & $\begin{array}{l}\text { Diplomatik ve ticarî faaliyetlerde yer } \\
\text { alması nedeniyle son derece önemli bir }\end{array}$ \\
\hline
\end{tabular}




\begin{tabular}{|l|l|l|}
\hline & $\begin{array}{l}\text { Esther kitabı); edebiyat, özellikle şiir } \\
\text { (Gllgamış Destanı). }\end{array}$ & $\begin{array}{l}\text { konuma sahipler. Yazmanlar ve bilginler } \\
\text { elit sınıfa mensuplar. }\end{array}$ \\
\hline Eski Yunan & $\begin{array}{l}\text { Tercümanlar; rüyalar, rivayetler sözler, } \\
\text { vb. konularda danışanlar için yorum } \\
\text { yapardı. Dinî (İbranice) metinler; } \\
\text { özellikle Torah çevirisi. }\end{array}$ & $\begin{array}{l}\text { Tanrının habercisi, tüccarların, hırsızların } \\
\text { ve bereketin de Tanrısı olan Hermes'le } \\
\text { özdeşleştirilir. Dinî metinlerde sözcüğü } \\
\text { sözcügüne çeviri önemli. }\end{array}$ \\
\hline $\begin{array}{l}\text { Ptolemaios Mısır'ı } \\
\text { Dönemi (I.Ö. 305- } \\
\text { İOO. 30) }\end{array}$ & $\begin{array}{l}\text { Devletler arası görüşmelerde aracılık } \\
\text { görevi Dinî metinler, özellikle Torah } \\
\text { çevirisi }\end{array}$ & $\begin{array}{l}\text { Kaynaklara bakıldığında toplumda çok } \\
\text { önemli bir konuma sahip değil. Literatürde } \\
\text { bu konuda çok fazla bilgi bulunmuyor. }\end{array}$ \\
\hline $\begin{array}{l}\text { Antik Roma } \\
\text { Edebiyat, tarım, cerrahi uygulamalar. }\end{array}$ & $\begin{array}{l}\text { Toplumda saygin bir konuma sahip. Roma } \\
\text { elit sinıfın bir üyesi olarak kabul edilir. }\end{array}$ \\
\hline $\begin{array}{l}\text { Hıristiyan dünyası } \\
\text { (Roma } \\
\text { İmparatorluğu'nun } \\
\text { bölündüğü 395 } \\
\text { yılına kadar olan } \\
\text { dönem) }\end{array}$ & İncil çevirileri & $\begin{array}{l}\text { Dinî metinlerin toplum ve yönetim } \\
\text { açısından çok önemli olması nedeniyle } \\
\text { çevirmenler de saygın bir konuma sahip. }\end{array}$ \\
\hline
\end{tabular}

Yukarıdaki tablodan da görüldüğü gibi, çevirilerin hangi alanlarda yapılacağını daha çok dönemin şartları belirlemiştir. Örneğin, İlkçağda eski Mısır'da devletlerin gelişim sürecinde olmaları ve komşularıyla olan ilişkilerinde kendilerini kanıtlama gereksinimi nedeniyle diplomatik, ticarî ve askerî faaliyetler ön plana çıkmakta ve dolayısıyla bu konularda çeviriler ağırlık kazanmaktadır. Bu dönemde çevirmen aynı zamanda bir diplomat olup, toplumun yedi sosyal sınıfından birini oluşturmakta ve soylu sınıfa mensup olarak görülmektedir. Antik dönemde Mezopotamya'da yapılan çevirilere bakıldığında çok fazla olmadı̆̆ı görülür. Kaynaklarda yer alan bilgilere göre, Mezopotamya'da adı geçen dönemde dinî konular ve Gılgamış Destanı gibi edebiyat çevirilerinin öne çıktı̆̆ı görülür. Kaynaklarda çok fazla bilgi bulunmasa da Mezopotamya'da farklı dilleri konuşan insanların resmî veya resmî olmayan ortamlarda siyasî, ekonomik, askerî, dinî ve özel konularda hem bağımsız olarak hem de az ya da çok nitelikli tercümanlar vasıtasıyla iletişim kurmaya çalıştıkları görülmektedir. Eski Yunan'da ise çevirmenler, bir yönden danışman gibi görev yapmakta, rivayetler, rüyalar, sözler gibi konularda danışan kişiye yorum yapmakta yani danışanın duygularına tercüman olmaktadır. Ayrıca bu dönemde dinî metinler, özellikle de İbranice metinlerin çevirisi öne çımaktadır (özellikle Torah çevirisi). Eski Yunanda tercümanların konumuna bakıldığında, tanrının habercisi, tüccarların, gezginlerin, hırsızların ve bereketin de tanrısı olan Hermes'le özdeşleştirildiği ve metnin anlamının bozulmasının ihanet gibi görülmesi nedeniyle dinî metinlerde sözcüğü sözcügüne çeviri yapıldığı görülmektedir. Ptolemaios Mısır'ında da yine dinî metinler, özellikle Torah çevirisinin öne çıktığı görülür ve tercümanların konumu ile ilgili olarak kaynaklarda çok fazla bilgi bulunmasa da diplomatik ilişkilerde tercümanlardan faydalanıldığı görülmektedir. Yunanlıların kaynak olarak kabul edilmesi nedeniyle, Antik Roma'da başta edebiyat olmak üzere, tarım, cerrahi uygulamalar ve ekonomi gibi konularda çeviriler dikkat çekmektedir. Bu dönemde tercümanın saygın bir konuma sahip olduğu, Roma elit sınıfın bir üyesi olarak kabul edildiği görülmektedir. Roma İmparatorluğu'nun bölündüğü tarih olan 395 yılına kadar olan Hıristiyan dünyasında İncil çevirilerinin bütün diğer alanların öne geçtiği görülür. Dinî metinlerin toplum ve yönetim açısından çok önemli olması nedeniyle çevirmenlerin de saygın bir konuma sahip olduğu ifade edilebilir.

\section{Sonuç}

Çeviri olgusunun başlangıç dönemi olarak kabul edilen Antik dönemde yazılı çevirinin ortaya çıkmasında birtakım gelişmeler etkili olmuştur. Bu gelişmelerden ilki, ulaşım araçlarının gelişmesi, 
savaşlar nedeniyle yabancı bölgelere gidip farklı insanların birbirlerini yakından tanıması, ticarî ilişkilerin başlamasıyla şehirleşmenin başlaması ve farklı kültürlerdeki insanların birbirlerini yakından tanımasıdır. İkinci gelişme ise, yazı kültürünün toplumsal yaşamın bir parçası olmasıdır. İ.Ö. 330o'de Mezopotamya'da Sümerlerin çivi yazısını kullanmaya başlamalarıyla başka medeniyetler de kendi alfabesini oluşturma çabası içine girmiş, toplumsal yaşamı düzenleyen kuralları kağıda döken yazılı dilin daha kalıcı olması sonucunu ortaya koymuştur. Eski Mısır'da çeviri faaliyetleri hakkında çok fazla belge bulunmamaktadır ancak yapılan kazılarda ortaya çıan bazı tabletler o dönemin çeviri faaliyetleri hakkında kısmen de olsa bilgi vermektedir. İ.Ö. 1370 yılına doğru Akhénaton tarafından başkent ilân edilen Tell El-Amarna yerleşim bölgesinde, üzerinde çivi yazısı şekilleri olan ve otuz ylllı bir dönemde çeşitli kuzey-doğu ülkeleri ile yazışmaları temsil eden 382 tablet bulunmuş (Ballard, 2013: 10) ve bunlar Amarna Mektupları olarak adlandırılmıştır. Bu tabletlerin muhtemelen el yazması eğitimi ve çeviri sürecini içerdiği, ayrıca içinde Akad ve Mısır dilinde sözlük benzeri bir liste, hece tablosu bölümü, birkaç el yazma alıştırması ve edebî metinleri kapsadığı ifade edilmektedir. Bu arşivlerin çoğunluğunun gelen mektuplardan oluştuğunu ve içeriklerinin, yönetim işlerini, devlet adamları arasındaki ilişkileri, evlilik hazırlıklarını, hediye gönderimi, vb. konuları ele aldığı düşünülmektedir. Mezopotamya'da epik şiir, tarihî kronikler, adlî belgeler, kehanet metinleri, ilahiler, dualar ve ağıtlar, mektup ve atasözleri, toplumsal hiciv ve erotik şiirler gibi çok zengin bir hazineye sahip olup, eski Mezopotamya'nın en önemli şiirlerinden biri Gılgamış Destanı'dır. Medeniyet uyanışları bağlamında ilk uyanış hareketinin Eski Yunan uyanışı olduğunu dile getiren Ülken (2009: 9), Batıda özellikle bu devrin hayranları arasında, bu uyanışın kendiliğinden doğmuş gibi göründüğünü ve bu nedenle 'Yunan mucizesi' denmesinin bir âdet haline geldiğini, ancak yapılan araştırmalarda Yunan ilminin üç kaynaktan geldiğini belirtir ve bu kaynakların da Sümerler, Fenikeliler ve Mısırlılar olduğunu ifade eder. Eski Mısır'da V. Ptolemaios (ì.Ö. 210-181) döneminden günümüze kalan ve şüphesiz Antik Dönemin en önemli çevirilerinden birini taşıyan Rosetta Taşı'dır. Daha büyük bir taş levhanın kırık bir parçası olan Rosetta Taşı’nın üzerinde bulunan yazı, kral Ptolemaios (İ.Ö. 204-181) ile ilgili resmi bir yazı içermekte ve 14 satırdan oluşmaktadır. Çeviri tarihinin başlangıcı olarak kabul edilen Antik Roma döneminde, yeni bir çeviri bilinci ve çevirmenin belirleyici işlevine ilişkin bazı görüşler oluşmaya başlamıştır. Romalıların başka bir kültüre, edebiyat dizgesine ait bir düşünceyi veya yapıtı kendilerine mal etme anlayışının çeviriye de yansıdığını dile getiren Yücel (2007: 34), bunun nedeninin, Romalıların uygulayıcı ve yararcı bir dünya görüşüne sahip olmalarından kaynaklandığını belirtir ve bunun sonucu olarak 'serbest' bir çeviri biçimi olarak adlandırılan bir yaklaşımın ağırlık kazandığını ifade ederek kaynak metne öykünmeye çalışmayan bu yaklaşımda daha önce olduğu gibi kaynak metindeki sözcüklerin odak olarak alınmadığını ve konunun erek dil dizgesi açısından ele alındığını belirtir ve bunun en belirgin kanıtının da ilk edebî metin çevirisi olan Livius Andronicus (İ.Ö. 284-205)'un İ.Ö. 240 yılında Yunancadan Latinceye çevirdiği Homeros'un Odysseia'sı olduğunu ifade eder. Dönemin en önemli siması Marcus Tillius Cicero (i̇.Ö. 106-43) olup Roma'nın en büyük hatibi olmasının yanı sıra Yunanca düşünce ve metinlerini Latinceye çeviren büyük bir çevirmen ve Roma'nın çeviri üzerine yazan en ünlü yazarı kabul edilir. Hıristiyan dünyasında, İncil çevirileri çok önemli bir yer tutmaktadır. Latince Eusebius Hieronymus olarak bilinen Saint Jerome, bu döneme damgasını vurmuş ve çeviri tarihini etkilemiş önemli bir kişiliktir. Vetus Latina, St Jerome'un Vulgata'sının Latince konuşan Batılı Hıristiyanlar için standart İncil olmadan önce çevirisi yapılan Latince İncil metinlerine verilen ortak bir isim olup Vetus Latina ifadesi Eski Latince yerine kullanılır ve bazen Eski Latince İncil olarak bilinir. Hieronymus'un çeviri alanındaki en önemli katkısı ‘sözcüğü sözcüğüne' ve 'anlamına göre' kavramlarını getirmiş olmasıdır. Pammachius'a yazmış olduğu 'On the Best Method of Translation' başlıklı mektupta (57. Mektup), bu kavramlara değinmiş, çevirmenlerin çeviri esnasında karşılaştıkları zorluklar ile Eski ve Yeni Ahit (Vulgate)'in Latince çevirilerinin arkasında yatan sebepleri nasıl desteklediğini açıkladığını ifade etmiştir. 
Konstantinopolis şehrinin kurulmasıyla Roma İmparatorluğu doğu ve batı merkezli bir imparatorluk haline gelmiş, başlangıçta siyaseten ve hukuken birbirine bağlı olan doğu ve batının zamanla birbirinden ayrılma eğilimine girmiş ve I. Theodosius'un kendi hanedanlığını kurmak düşüncesiyle ölmeden önce imparatorluk topraklarını oğulları arasında taksim etmesinin imparatorluğu giderek içinden çıkılmaz bir hale sokmuş ve Roma İmparatorluğu'nun sonunu getirmiştir.

\section{Kaynaklar}

Al-Ali, K. K. \& Majid, L. R. (2015). "St Jerome's Approach to Word-for-Word ans Sense-for-Sense Translation" Journal of the College of Arts, University of Basra, No. 74, 2015.

Augoustakis, A. \& A. Traill, (2013). A Companion to Terence. UK: Blackwell Publishing Ltd.

Ballard, M. (2013). Histoire de la Traduction - Repères Historiques et Culturels. Bruxelles: De Boeck Supérieur s.a.

Bartsch, S. (2016) "Roman Literature: Translation, Metaphor \& Empire", the American Academy of Arts \& Sciences, 145 (2), Spring 2016.

Bertman, S. (2003). Handbook to Life in Ancient Mesopotamia. New York: Facts on File, Inc.

Bloch, J. (1919). "The Authorship of the Peshitta". The American Journal of Semitic Languages and Literatures, Jul., 1919, Vol. 35, No. 4, pp. 215-222.

Chrobak, M. (2013). "For a tin of ingot: the archaeology of oral interpretation", Przeklananiec. AJournal of Literary Translation. Special Issue (2013): 87-101.

Delisle, J. \& Woodsworth, J. (2012). Translators through History. Amsterdam: John Benjamins.

Dole, N. H. (1905). The Latin Poets. New York: Thomas Y. Crowell \& Co. Publishers.

Ebbinghaus, E. A. (1991). “Ulfila(s) or Wulfila?”. Historische Sprachforschung / Historical Linguistics, 1991, 104. Bd., 2. H. (1991), pp. 236-238.

Frauzel, J. (1984). "Wulfila's Fourth Century Gothic Bible Translation," Deseret Language and Linguistic Society Symposium, Vol. 10, Iss. 1, Article 11.

Guidère, M. (2008). Introduction a la Traductologie. Bruxelles: Groupe de Boeck s.a.

Hölbl, G. (2001). A History of the Ptolemaic Empire. New York: Routledge.

Köroğlu, K. (2006). Eski Mezopotamya Tarihi - Başlangıcından Perslere Kadar. İstanbul: İletişim.

Kuiper, K. (2011). Ancient Egypt - From prehistory to the Islamic Conquest. New York: Britannica Educational.

Largent, R.P. (1900). Saint Jérôme, Paris: Librairie Victor Lecoffre.

McElduff, S. (2013). Roman Theories of Translation - Surpassing the Source. New York: Routledge.

Mcintosh, J. R. (2005). Ancient Mesopotamia - New Perspectives. California: ABC-CLIO, Inc.

Moatti, C. (2006). "Translation, Migration, and Communication in the Roman Empire: Three Aspects of Movement in History”. Classical Antiquity, 25 (1): 109-140 (2006).

Njozi, H. M. (1990). “The Flood Narrative in the Gilgamesh Epic, the Bible and the Qur'an: theProblem of Kinship and Historicity." Islamic Studies, Autumn 1990, Vol. 29, No. 3, pp. 303-309.

Ochman, K. (2013). "Translation Criticism in Ancient Rome. Aulus Gelliusi Attic Nights". Przekladaniec A Journal of Literary Translation, special issue (2013): 71-86.

Orlinsky, H. M. (1936). “The Columnar of the Hexapla”. The Jewish Quarterly Review, Oct., 1936, New Series, Vol. 27, No. 2, pp. 137-149.

Paker, S. (1987). "Tanzimat döneminde Avrupa edebiyatından çeviriler: Çoğuldizge kuramı açısından bir değerlendirme", Çeviri Seçkisi I: Çeviriyi Düşünenler, M. Rifat, (Derleyenler), 26-42, İstanbul: Dünya. 
1280 / RumeliDE Journal of Language and Literature Studies 2021.25 (December)

Translation actvities in the Antique Age: A study on the characteristics of the translations and the situation of the translators / R. Hatipoğlu (pp. 1258-1280)

Pearce, L. E. (1995). Civilizations of the Ancient Near East (ed. Jack M. Sasson). Volume IV, CharlesScribner's Sons MacMillan Library Reference USA, New York: Simon \& Schuster Macmillan.

Shaw, I. (2004). Ancient Egypt - A Very Short Introduction. New York: Oxford University Press.

Stambusky, A. (1977). "Roman Comedy on Trial in the Republic: The Case of Cencorship against Gnaeus Naevius the Playwright”. Educational Theatre Journal, Mar., 1977, Vol. 29, No. 1, pp. 29-36.

Ülken, H.Z. (2011). Uyanış Devirlerinde Tercümenin Rolü. İstanbul: Türkiye İş Bankası Kültür.

Yücel, F. (2016). Çevirinin Tarihi. İstanbul: Çeviribilim.

Weiss, M. (2004). Studies in Classics (ed. Dirk Obbing \& Andrew Dyck), New York: Routledge. 